\title{
Quantitative relationships between benthic diatom assemblages and water chemistry in Macquarie Island lakes and their potential for reconstructing past environmental changes
}

\author{
KRYSTYNA M. SAUNDERS ${ }^{1 *}$, DOMINIC A. HODGSON ${ }^{2}$ and ANDREW MCMINN ${ }^{1}$ \\ ${ }^{1}$ Institute of Antarctic and Southern Ocean Studies, University of Tasmania, Private Bag 77, Hobart, TAS 7001, Australia \\ ${ }^{2}$ British Antarctic Survey, NERC, High Cross, Madingley Road, Cambridge CB3 OET, UK \\ *saunderk@utas.edu.au
}

\begin{abstract}
This study is the first published survey of diatom-environment relationships on sub-Antarctic Macquarie Island. Fifty-eight sites in 50 coastal and inland lakes were sampled for benthic diatoms and water chemistry. 208 diatom species from 34 genera were identified. Multivariate analyses indicated that the lakes were distributed along nutrient and conductivity gradients. Conductivity, pH, phosphate (SRP), silicate and temperature all explained independent portions of the variance in the diatom data. Transfer functions provide a quantitative basis for palaeolimnological studies of past climate change and human impacts, and can be used to establish baseline conditions for assessing the impacts of recent climate change and the introduction of non-native plants and animals. Statistically robust diatom transfer functions for conductivity, phosphate and silicate were developed, while $\mathrm{pH}$ and temperature transfer functions performed less well. The lower predictive abilities of the $\mathrm{pH}$ and temperature transfer functions probably reflect the broad $\mathrm{pH}$ tolerance range of diatoms on Macquarie Island and uneven distribution of lakes along the temperature gradient. This study contributes to understanding the current ecological distribution of Macquarie Island diatoms and provides transfer functions that will be applied in studies of diatoms in lake sediment cores to quantitatively reconstruct past environmental changes.
\end{abstract}

Received 27 November 2007, accepted 12 March 2008

Key words: climate change, limnology, management, palaeolimnology, sub-Antarctic, transfer function

\section{Introduction}

Recent research suggests that the Southern Ocean exerts a powerful influence on global climate (Rintoul et al. 2001). Macquarie Island is one of the few islands in the Southern Ocean and provides an important site for investigating climate change. An understanding of past magnitudes and rates of climate change is fundamental for putting the present into context and making realistic predictions about the future.

However, to date there have been few attempts at reconstructing past climate change at Macquarie Island, and more generally in the region between $40-65^{\circ} \mathrm{S}$. This is surprising as Macquarie Island is well placed to respond to changes in rainfall, temperature and westerly wind patterns associated with changes in the thermal gradient between temperate and polar latitudes, the position of the Polar Frontal Zone and sea ice extent.

Macquarie Island contains numerous lakes and ponds, many of which accumulate sediments that archive a record of past environmental conditions. Unlocking this record can be achieved through palaeolimnological studies. Diatoms are one of the key tools used in these studies as they respond to a wide range of environmental variables including nutrients, $\mathrm{pH}$, conductivity and temperature
(Stoermer \& Smol 1999). Quantitative methods have been developed to relate diatom species assemblages to specific environmental variables (i.e. diatom-based transfer functions). With these transfer functions, sub-fossil diatom assemblages in lake sediment cores can be used to reconstruct past environmental conditions and can be applied to investigations of recent climate change and human impacts (see Battarbee et al. 2001).

High-latitude diatom-based transfer functions have previously been developed for inferring nutrients (e.g. Lim et al. 2007), salinity (e.g. Verleyen et al. 2003, Sabbe et al. 2004, Hodgson et al. 2006), pH (e.g. Jones \& Birks 2004), chlorophyll $a$ (e.g. Jones \& Juggins 1995), temperature (e.g. Kumke et al. 2004, Gremmen et al. 2007) and soil moisture content (e.g. Van de Vijver et al. 2002a). To date, with the exception of Van de Vijver et al. (2002a) and Gremmen et al. (2007), there are no diatom-based transfer functions from the sub-Antarctic despite good evidence that the composition of diatom assemblages in this region is strongly influenced by environmental gradients (e.g. Van de Vijver et al. 2002b, 2004).

The relationships between diatom community composition and environmental variables on Macquarie Island have not yet been fully explored. In this paper we 


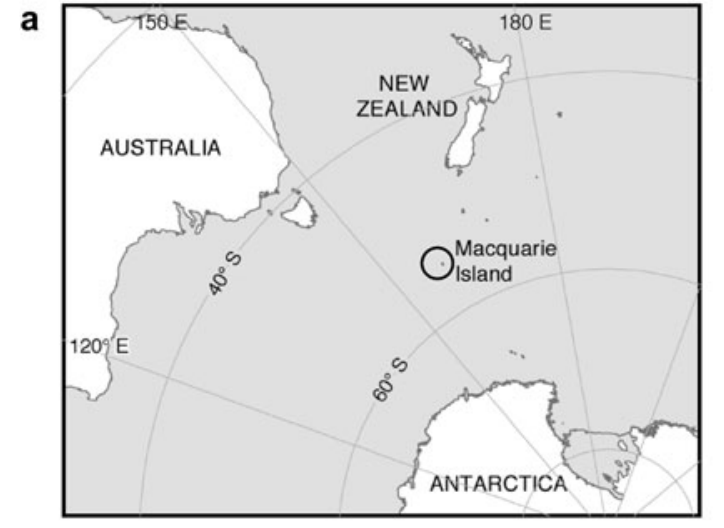

C

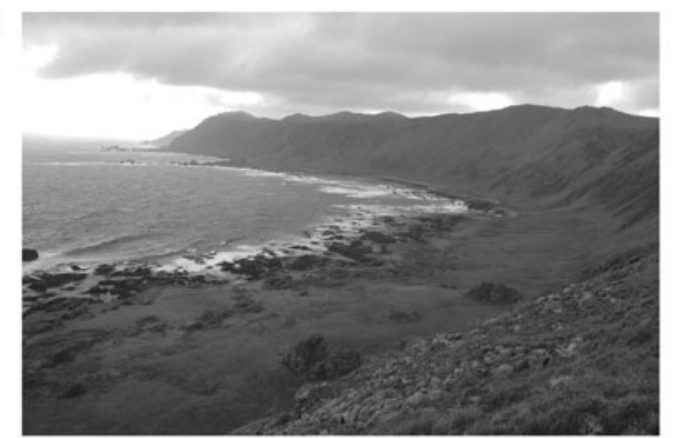

d

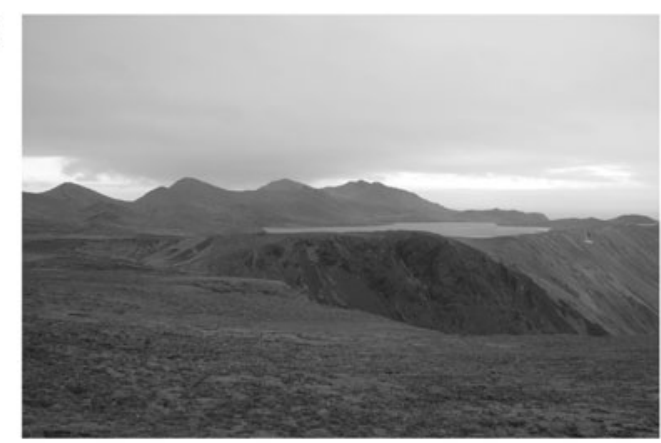

b

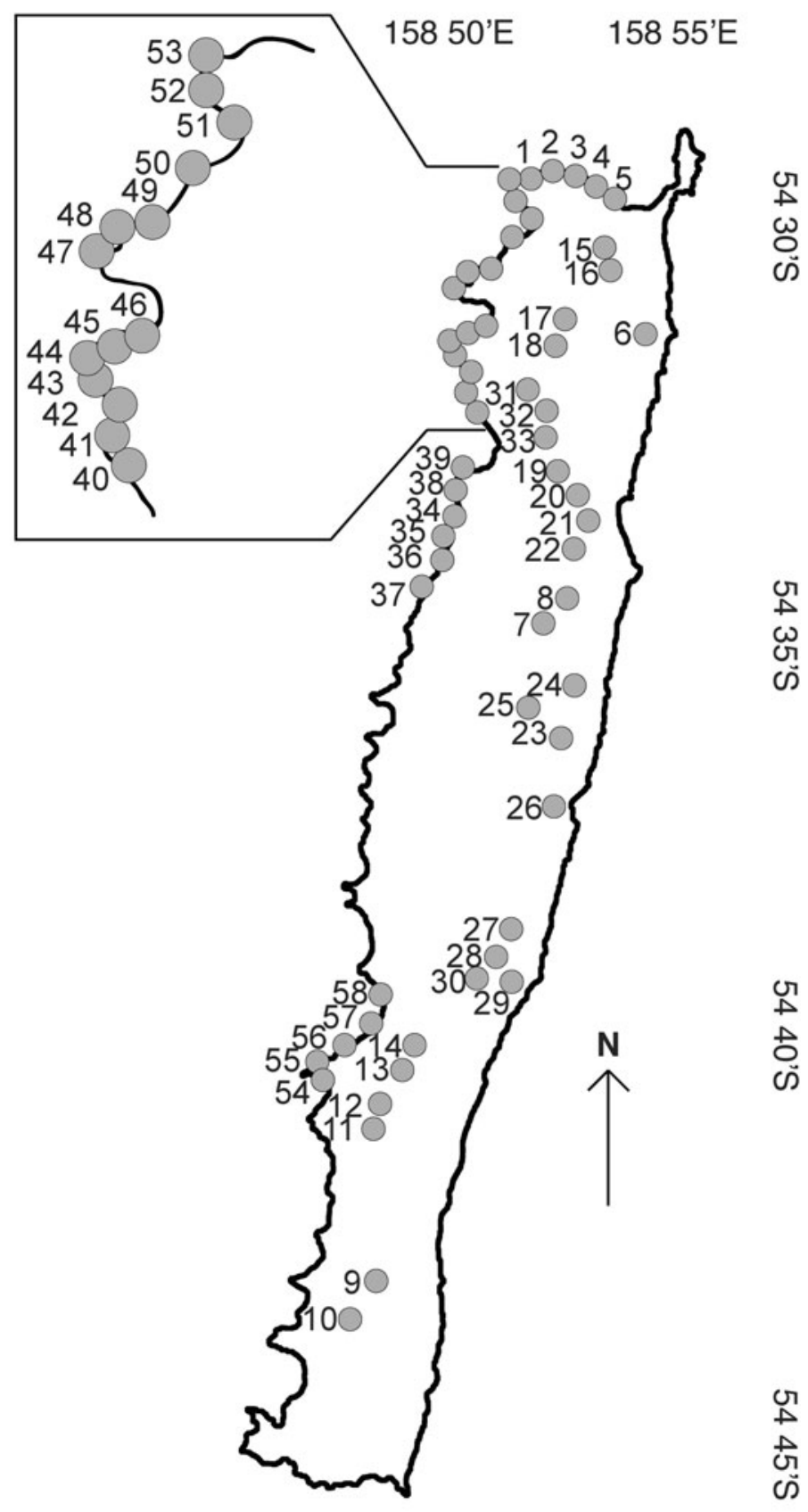

$5 \mathrm{~km}$

Fig. 1. a. Location of Macquarie Island, situated south of New Zealand and Australia, and north of Antarctica, b. Location of sampling sites, c. looking north from the south-west coast of Macquarie Island, illustrating the coastal terrace and plateau that characterizes the island, and d. looking south down the western side of the plateau. Please note: detailed topographic maps are available from http://aadc-maps.aad.gov. au/aadc/mapcat/

present new data from lakes and ponds on Macquarie Island and quantify the relationships between surface sediment diatom assemblages and present day environmental conditions. These relationships are then used to develop diatom-based transfer functions that will be applied to future studies of environmental change on the island.

\section{Study area}

Macquarie Island $\left(54^{\circ} 30^{\prime} \mathrm{S}, 158^{\circ} 57^{\prime} \mathrm{E}\right)$ is located just north of the Polar Front, $1500 \mathrm{~km}$ south-east of Tasmania, $1200 \mathrm{~km}$ south-west of New Zealand and $1300 \mathrm{~km}$ from the Antarctic continent (Fig. 1). It is $34 \mathrm{~km}$ long, $5 \mathrm{~km}$ at its widest and has an area of $120 \mathrm{~km}^{2}$. 
The island experiences a cool, wet and windy oceanic climate with small annual and diurnal variations in temperature. The weather is dominated by westerly to north-westerly winds, with a mean annual wind speed of $\sim 30 \mathrm{~km} \mathrm{hr}^{-1}$, reaching gale forces of up to $170 \mathrm{~km} \mathrm{hr}^{-1}$. Mean annual precipitation is $920 \mathrm{~mm}$ and it rains $>300$ days per year (BOM 2007, www.bom.gov.au/weather/tas/ macquarie/). Due to almost constant cloud cover, light levels are generally low, with a mean annual average of 2.2 hours of sunshine per day (BOM 2007). Mean temperature ranges between $4.9^{\circ} \mathrm{C}$ in winter and $8.8^{\circ} \mathrm{C}$ in summer, with a daily variation of $\sim 3.5^{\circ} \mathrm{C}$ (BOM 2007). Since continuous meteorological observations began in 1949 , mean surface air temperature has increased by $0.3^{\circ} \mathrm{C}$ degrees (Tweedie \& Bergstrom 2000).

Geologically, Macquarie Island is a rare example of uplifted oceanic crust that is part of the Macquarie Ridge Complex, which runs south from New Zealand (Davis 1988). Faulting, uplift, sea level changes, erosion and periglacial processes have been the major factors shaping Macquarie Island and its lakes. While the occurrence of past glacial activity has been debated, it is now believed that glaciation did not play a significant role in shaping the current landscape (Selkirk et al. 1990), although it is still debatable if permanent snow and ice accumulated in some areas during the Last Glacial Maximum (McGlone 2002).

The island consists of a steep sided (generally $20-40^{\circ}$ ) narrow plateau, rising directly from the coast or raised beach terraces and averages $250-300 \mathrm{~m}$ above sea level, with its highest point at $433 \mathrm{~m}$. Macquarie Island is extensively vegetated with tussock grasslands, herbs and sedges, areas of peat, mosses, liverworts and lichens, and there are no trees (Fig. 1).

The island is also home to abundant wildlife, providing a vital refuge and important breeding ground in a region of sparse landmasses. In recognition of its geological and wildlife attributes, Macquarie Island has been designated as a Sanctuary (1933), a Tasmanian State Reserve (1978), World Heritage Area (1997) and United Nations Educational, Scientific and Cultural Organization Biosphere Reserve (the only Biosphere Reserve in the sub-Antarctic biogeographic region). The adjacent seas are designated as a Marine Park and form the second largest Marine Protected Area in the world. Nevertheless, human impacts on the island have been significant since its discovery in 1810 . Early interest in the island was purely commercial, based on exploitation of penguin and seal resources (Davis 1988). During this period a number of alien vertebrate species were introduced including cats (Felis catus, 1820s), European rabbits (Orycolagus cuniculus, 1870s), weka (Galliralluss australis scotti, 1870s), house mice (Mus musculus, 1890s) and ship rats (Rattus rattus, 1900) (Copson \& Whinam 2001). In 1919 the commercial exploitation of penguins and seals was terminated (Brothers \& Copson 1988), but introduced species continue to threaten its fragile habitats and conservation status. Cats and weka have recently been eradicated (2000 and 1989 respectively, PWS 2007), but this has intensified damage by rabbits, particularly through vegetation disturbance and erosion.

The island is characterized by abundant shallow and deep ponds and lakes. Oceanic spray is the principal source of ions to the lakes, with geochemical weathering playing a minor role (Buckney \& Tyler 1974). The ion chemistry of the lakes is influenced by the prevailing westerly winds and distance from the ocean, and seasonal variation in chemical composition is small (Buckney \& Tyler 1974, Bryden 1988).

\section{Methods}

\section{Data collection}

Fifty-eight sites in 50 ponds and lakes on the coastal terrace and plateau were sampled during a six week period from FebruaryApril 2006. These sites include most ponds and lakes on Macquarie Island. The largest four lakes were sampled at two locations (at the western and eastern sides) to try and account for spatial variability in nutrients and conductivity. At each site, surface sediment samples (top $1 \mathrm{~cm}$ ) were collected from c. $1 \mathrm{~m}$ water depth using a hand-operated gravity corer (Glew 1991). While there are a few deep lakes on Macquarie Island, most are shallow and only $1-2 \mathrm{~m}$ deep. Consequently, samples were collected from $c .1 \mathrm{~m}$ depth throughout the sampling campaign. At each site, surface water conductivity, dissolved oxygen, $\mathrm{pH}$, temperature and turbidity were measured using a Hydrolab Datasonde 4a. Duplicate water samples were collected for soluble reactive phosphate (SRP), nitrate/nitrite and silicate analyses. Sample tubes were rinsed several times in lake water at each site prior to collection. Samples for nutrient analysis were frozen as soon as possible after collection and analysed using an Alpkem Autoanalyzer (Continuous Flow Solution Analyzer) at the Commonwealth Scientific and Industrial Research Organization Marine and Atmospheric Laboratories, Hobart, in May 2006. The autoanalyser uses the principles of colorimetric analysis in a continuous flow system with all manipulations of the samples automated. Each analytical channel was calibrated using standards of known concentration (Eriksen 1997).

\section{Diatom analysis}

Diatom samples were prepared using standard methods (Battarbee et al. 2001). At least 400 frustules were counted per sample, using phase contrast and oil immersion at 1000x magnification on a Zeiss Z20 light microscope. The relative abundance of all species (including unidentified forms) was recorded as a percentage of the total number of frustules counted (Battarbee et al. 2001). Taxonomy was principally based on sub-Antarctic (e.g. Van de Vijver et al. 2002b), Antarctic (i.e. Roberts \& McMinn 1999) and Australian taxonomic literature (e.g. Vyverman et al. 1995, Hodgson 
Table I. Environmental data recorded from Macquarie Island lakes.

\begin{tabular}{|c|c|c|c|c|c|c|c|c|c|c|c|}
\hline Site no. & Type & Easting & Northing & $\begin{array}{l}\text { Temp } \\
\left({ }^{\circ} \mathrm{C}\right)\end{array}$ & $\mathrm{pH}$ & $\begin{array}{c}\text { SpCond } \\
\left(\mu \mathrm{S} \mathrm{cm}^{-1}\right)\end{array}$ & $\begin{array}{c}\mathrm{DO} \\
\left(\mathrm{mg} \mathrm{L}^{-1}\right)\end{array}$ & $\begin{array}{c}\text { Turb } \\
\text { (NTU) }\end{array}$ & $\begin{array}{c}\mathrm{Si} \\
\left.(\mu \mathrm{g} \mathrm{Si} \mathrm{L})^{-1}\right)\end{array}$ & $\begin{array}{c}\text { SRP } \\
\left(\mu \mathrm{g} \mathrm{P} \mathrm{L}^{-1}\right)\end{array}$ & $\begin{array}{c}\mathrm{N} \\
\left(\mu \mathrm{g} \mathrm{N} \mathrm{L}{ }^{-1}\right)\end{array}$ \\
\hline 1 & $\mathrm{c}$ & 493055 & 3961062 & 10.83 & 5.74 & 522 & 10.23 & 146 & 31.11 & 294.2 & 262.8 \\
\hline 2 & $\mathrm{c}$ & 493067 & 3961112 & 10.24 & 6.26 & 608 & 4.73 & 58 & 107.9 & 1951 & 3545 \\
\hline 3 & $\mathrm{c}$ & 493259 & 3960999 & 9.28 & 7.07 & 559 & 10.17 & 32 & 177.1 & 380.6 & 1514 \\
\hline 4 & $\mathrm{c}$ & 493516 & 3960937 & 9.30 & 7.40 & 555 & 10.40 & 391 & 414.8 & 260.6 & 4636 \\
\hline 5 & $\mathrm{c}$ & 493873 & 3960714 & 9.70 & 7.40 & 406 & 10.66 & 7 & 364.6 & 24.30 & 7.45 \\
\hline 6 & $\mathrm{i}$ & 495374 & 3956986 & 13.48 & 9.95 & 255 & 12.33 & 9 & 11.75 & 188.6 & 33.59 \\
\hline 7 & $\mathrm{i}$ & 492867 & 3949922 & 8.44 & 6.47 & 164 & 11.11 & 6 & 2.15 & 0.00 & 0.98 \\
\hline 8 & $\mathrm{i}$ & 492954 & 3950051 & 8.47 & 6.48 & 164 & 11.09 & 7 & 2.88 & 0.22 & 1.88 \\
\hline 9 & $\mathrm{i}$ & 488472 & 3933817 & 7.39 & 7.46 & 224 & 11.35 & 9 & 65.90 & 1.99 & 5.80 \\
\hline 10 & $\mathrm{i}$ & 488566 & 3933546 & 7.35 & 7.21 & 223 & 11.50 & 16 & 73.21 & 3.97 & 4.91 \\
\hline 11 & $\mathrm{i}$ & 488549 & 3938611 & 6.93 & 6.35 & 215 & 11.52 & 10 & 5.65 & 1.40 & 7.65 \\
\hline 12 & $\mathrm{i}$ & 488395 & 3938844 & 6.74 & 6.52 & 215 & 11.55 & 9 & 3.15 & 0.64 & 3.29 \\
\hline 13 & $\mathrm{i}$ & 488468 & 3939570 & 7.45 & 7.10 & 265 & 11.27 & 9 & 8.91 & 2.27 & 0.72 \\
\hline 14 & $\mathrm{i}$ & 488857 & 3940204 & 7.87 & 7.08 & 265 & 11.33 & 10 & 11.81 & 3.34 & 5.61 \\
\hline 15 & $\mathrm{i}$ & 494279 & 3958913 & 4.86 & 6.59 & 183 & 12.07 & 12 & 24.14 & 4.81 & 30.08 \\
\hline 16 & $\mathrm{i}$ & 494218 & 3958818 & 5.86 & 6.98 & 179 & 11.66 & 7 & 69.55 & 24.49 & 15.48 \\
\hline 17 & $\mathrm{i}$ & 492881 & 3957684 & 5.44 & 6.83 & 179 & 12.06 & 9 & 192.8 & 0.67 & 0.15 \\
\hline 18 & $\mathrm{i}$ & 492767 & 3957255 & 5.49 & 7.01 & 179 & 11.80 & 8 & 92.31 & 0.04 & 4.75 \\
\hline 19 & $\mathrm{i}$ & 493436 & 3953044 & 7.03 & 8.72 & 280 & 12.16 & 276 & 820.5 & 93.13 & 14.72 \\
\hline 20 & $\mathrm{i}$ & 493432 & 3952816 & 7.10 & 8.75 & 278 & 11.81 & 16 & 648.4 & 163.1 & 125.6 \\
\hline 21 & $\mathrm{i}$ & 493247 & 3952211 & 6.64 & 6.84 & 164 & 11.69 & 31 & 7.03 & 0.73 & 9.51 \\
\hline 22 & $\mathrm{i}$ & 493101 & 3951912 & 6.40 & 6.79 & 164 & 11.61 & 7 & 2.80 & 0.28 & 1.27 \\
\hline 23 & $\mathrm{i}$ & 492954 & 3948077 & 7.50 & 7.33 & 146 & 11.81 & 7 & 14.08 & 4.56 & 2.25 \\
\hline 24 & $\mathrm{i}$ & 493025 & 3948123 & 8.16 & 7.40 & 139 & 11.70 & 6 & 68.15 & 2.94 & 9.68 \\
\hline 25 & $\mathrm{i}$ & 493029 & 3947950 & 7.79 & 6.85 & 116 & 11.54 & 9 & 9.19 & 5.35 & 8.57 \\
\hline 26 & $\mathrm{i}$ & 493223 & 3946260 & 8.29 & 7.26 & 209 & 11.34 & 9 & 1525 & 61.84 & 21.11 \\
\hline 27 & $\mathrm{i}$ & 491799 & 3942967 & 11.74 & 6.28 & 0 & 10.36 & 84 & 4.11 & 0.00 & 3.75 \\
\hline 28 & $\mathrm{i}$ & 491696 & 3942835 & 10.82 & 6.44 & 0 & 10.85 & 18 & 2.74 & 1.35 & 2.41 \\
\hline 29 & $\mathrm{i}$ & 491658 & 3941607 & 7.13 & 5.99 & 120 & 11.82 & 21 & 31.06 & 7.82 & 23.81 \\
\hline 30 & $\mathrm{i}$ & 491625 & 3941880 & 7.34 & 7.50 & 156 & 11.86 & 7 & 4.66 & 3.39 & 8.06 \\
\hline 31 & $\mathrm{i}$ & 492356 & 3955702 & 4.58 & 7.56 & 248 & 13.02 & 21 & 12.26 & 120.0 & 7.98 \\
\hline 32 & $\mathrm{i}$ & 492314 & 3955758 & 4.50 & 7.39 & 247 & 13.01 & 20 & 5.90 & 18.06 & 15.58 \\
\hline 33 & $\mathrm{i}$ & 492432 & 3955812 & 4.49 & 7.36 & 248 & 13.02 & 30 & 16.89 & 13.07 & 13.51 \\
\hline 34 & $\mathrm{c}$ & 490852 & 3953408 & 6.83 & 7.57 & 909 & 11.78 & 8 & 201.9 & 155.4 & 68.74 \\
\hline 35 & $\mathrm{c}$ & 490986 & 3952954 & 7.48 & 6.27 & 528 & 7.26 & 974 & 918.2 & 78.06 & 41.74 \\
\hline
\end{tabular}

$\mathrm{c}=$ coastal lake, $\mathrm{i}=$ inland lake, Temp $=$ Temperature, $\mathrm{SpCond}=$ specific conductivity, $\mathrm{DO}=$ dissolved oxygen, $\mathrm{Si}=$ silicate, $\mathrm{SRP}=$ soluble reactive phosphate, $\mathrm{N}=$ nitrate/nitrite.

et al. 1997). All taxa were photographed and are archived, including taxonomic data, with the first author. A final species list (of 129 species) was developed including only those species occurring with $\geq 1 \%$ relative abundance.

\section{Statistical analyses}

Multivariate statistical analyses were used to identify major environmental gradients in the dataset, explore diatomenvironment relationships and identify environmental variables that explained independent portions of the variance in the diatom data. Simple Weighted Averaging (WA) was used to determine species' ecological preferences (i.e. optima and tolerances) for these environmental variables and, together with Weighted Averaging Partial Least Squares (WAPLS), was used to develop transfer functions.
Prior to statistical analyses, each environmental variable was checked for skewness, and nutrients and turbidity were $\log (\mathrm{x}+1)$ transformed. Principal Component Analysis (PCA) was performed on the environmental data to determine the major environmental gradients. Detrended Correspondence Analysis (DCA) with detrending by segments and downweighting of rare species was performed on the species data (untransformed) to establish whether species distribution was unimodal or linear. As gradient lengths were greater than 2 standard deviation units, unimodal ordination techniques were used. Species data were $\log (\mathrm{x}+1)$ transformed for subsequent analyses.

A series of Canonical Correspondence Analyses (CCA) were performed with scaling focused on inter-species distances, biplot scaling and downweighting of rare species. Variance Inflation Factors (VIFs) were identified and any environmental variables with VIFs $>20$ were removed. CCAs with forward selection and Monte Carlo 
Table I. (Continued) Environmental data recorded from Macquarie Island lakes.

\begin{tabular}{|c|c|c|c|c|c|c|c|c|c|c|c|}
\hline Site no. & Type & Easting & Northing & $\begin{array}{l}\text { Temp } \\
\left({ }^{\circ} \mathrm{C}\right)\end{array}$ & $\mathrm{pH}$ & $\begin{array}{c}\text { SpCond } \\
\left(\mu \mathrm{S} \mathrm{cm}^{-1}\right)\end{array}$ & $\begin{array}{c}\mathrm{DO} \\
\left(\mathrm{mg} \mathrm{L}^{-1}\right)\end{array}$ & $\begin{array}{l}\text { Turb } \\
\text { (NTU) }\end{array}$ & $\begin{array}{c}\mathrm{Si} \\
\left(\mu \mathrm{g} \mathrm{Si} \mathrm{L}^{-1}\right)\end{array}$ & $\begin{array}{c}\text { SRP } \\
\left(\mu \mathrm{g} \mathrm{P} \mathrm{L}^{-1}\right)\end{array}$ & $\begin{array}{c}\mathrm{N} \\
\left(\mu \mathrm{g} \mathrm{N} \mathrm{L}{ }^{-1}\right)\end{array}$ \\
\hline 36 & $\mathrm{c}$ & 490935 & 3952984 & 7.48 & 7.03 & 625 & 12.25 & 26 & 1596 & 239.8 & 3327 \\
\hline 37 & $\mathrm{c}$ & 490859 & 3953144 & 8.57 & 6.73 & 1136 & 9.17 & 214 & 73.93 & 1029 & 181.1 \\
\hline 39 & $\mathrm{c}$ & 490752 & 3953720 & 5.45 & 7.82 & 1528 & 12.24 & 95 & 43.33 & 496.8 & 206.6 \\
\hline 40 & $\mathrm{c}$ & 491753 & 3955051 & 6.24 & 6.08 & 552 & 8.13 & 21 & 86.41 & 205.4 & 119.1 \\
\hline 41 & $\mathrm{c}$ & 491599 & 3955369 & 5.79 & 7.19 & 495 & 11.12 & 7 & 1090 & 17.20 & 153.6 \\
\hline 44 & $\mathrm{c}$ & 490767 & 3957116 & 6.32 & 7.25 & 1502 & 12.14 & 20 & 72.27 & 1461 & 6461 \\
\hline 45 & $\mathrm{c}$ & 490982 & 3957320 & 6.02 & 6.66 & 1244 & 10.75 & 9 & 504.7 & 9890 & 160.2 \\
\hline 46 & $\mathrm{c}$ & 491353 & 3958630 & 8.03 & 7.32 & 693 & 11.48 & 21 & 2459 & 1250 & 188.2 \\
\hline 47 & $\mathrm{c}$ & 491553 & 3958564 & 8.73 & 7.46 & 698 & 12.03 & 28 & 291.2 & 1558 & 5240 \\
\hline 48 & $\mathrm{c}$ & 491557 & 3958671 & 8.89 & 8.12 & 603 & 14.43 & 30 & 2706 & 217.4 & 28.51 \\
\hline 49 & $\mathrm{c}$ & 491956 & 3959447 & 13.13 & 8.13 & 732 & 13.59 & 1042 & 441.2 & 415.2 & 84.78 \\
\hline 54 & $\mathrm{c}$ & 487570 & 3939965 & 6.75 & 6.77 & 1176 & 11.51 & 6 & 99.53 & 807.8 & 1052 \\
\hline 55 & $\mathrm{c}$ & 487545 & 3939906 & 6.93 & 5.50 & 1478 & 10.44 & 10 & 78.74 & 101.2 & 116.5 \\
\hline 56 & $\mathrm{c}$ & 488208 & 3940384 & 7.61 & 6.61 & 646 & 10.97 & 36 & 96.16 & 2249 & 1936 \\
\hline 57 & $\mathrm{c}$ & 488376 & 3940530 & 7.31 & 6.69 & 1571 & 8.71 & 83 & 120.0 & 2806 & 8578 \\
\hline 58 & $\mathrm{c}$ & 489012 & 3941269 & 8.76 & 8.36 & 749 & 14.66 & 16 & 285.6 & 611.9 & 3523 \\
\hline \multirow[t]{4}{*}{ All sites } & & mean & & 7.65 & 7.15 & 527.4 & 11.43 & 121.6 & 370.1 & 538.1 & 831.1 \\
\hline & & median & & 7.42 & 7.15 & 343.0 & 11.55 & 16.00 & 82.58 & 110.6 & 33.62 \\
\hline & & $\min$ & & 4.49 & 5.50 & 0.00 & 4.73 & 6.00 & 2.15 & 0.00 & 0.15 \\
\hline & & $\max$ & & 13.48 & 9.95 & 1571 & 18.08 & 2724 & 2706 & 9890 & 8578 \\
\hline \multirow{2}{*}{$\begin{array}{c}\text { Coastal } \\
\text { sites }\end{array}$} & & mean & & 7.94 & 7.15 & 845.4 & 11.15 & 212.4 & 590.9 & 1016 & 1594 \\
\hline & & median & & 7.70 & 7.24 & 704.0 & 11.17 & 27.00 & 288.4 & 511.8 & 443.7 \\
\hline
\end{tabular}

$\mathrm{c}=$ coastal lake, $\mathrm{i}=$ inland lake, $\mathrm{Temp}=$ Temperature, $\mathrm{SpCond}=$ specific conductivity, $\mathrm{DO}=$ dissolved oxygen, $\mathrm{Si}=$ silicate, $\mathrm{SRP}=$ soluble reactive phosphate, $\mathrm{N}=$ nitrate/nitrite.

permutation tests $(\mathrm{p}<0.05)$ were used to identify which environmental variables explained independent portions of the variance in the diatom data. Variance partitioning was used to determine the amount of variation explained by each variable and the interaction between them. All ordinations were performed using the software program $\mathrm{R}$ (R Development Core Team 2006).

Species ecological preferences (i.e. optima and tolerances) were determined using simple WA. Transfer functions were developed using simple WA with inverse and classical deshrinking, and with/without tolerance downweighting, and WAPLS to determine which model led to the best performing transfer functions. Performance was assessed using leave-one-out cross validation (i.e. jackknifing). The transfer function for each environmental variable with the best correlation $\left(r^{2}\right)$, best predicted correlation $\left(\mathrm{r}_{\text {jack }}^{2}\right)$, lowest root mean squared error (RMSE) and lowest root mean squared error of prediction $\left(\mathrm{RMSE}_{\mathrm{p}}\right)$ was identified and used. Species ecological preferences and transfer functions were determined using the software program $\mathrm{C} 2$ version 1.4 (Juggins 2003).

\section{Results}

\section{Limnology}

Table I outlines the environmental data measured at each lake. The lakes were all freshwater and conductivity

Table II. Principal Component Analysis results of the environmental data.

\begin{tabular}{lccccc}
\hline Axes & 1 & 2 & 3 & 4 & $\begin{array}{c}\text { Total } \\
\text { variance }\end{array}$ \\
\hline $\begin{array}{l}\text { Eigenvalues } \\
\begin{array}{l}\text { Cumulative \% variance } \\
\text { of environmental } \\
\text { data }\end{array}\end{array}$ & 0.31 .2 & 48.1 & 60.4 & 66.2 & 1.000 \\
\begin{tabular}{l} 
Sum of all eigenvalues \\
\hline
\end{tabular} & & & & & \\
\hline
\end{tabular}




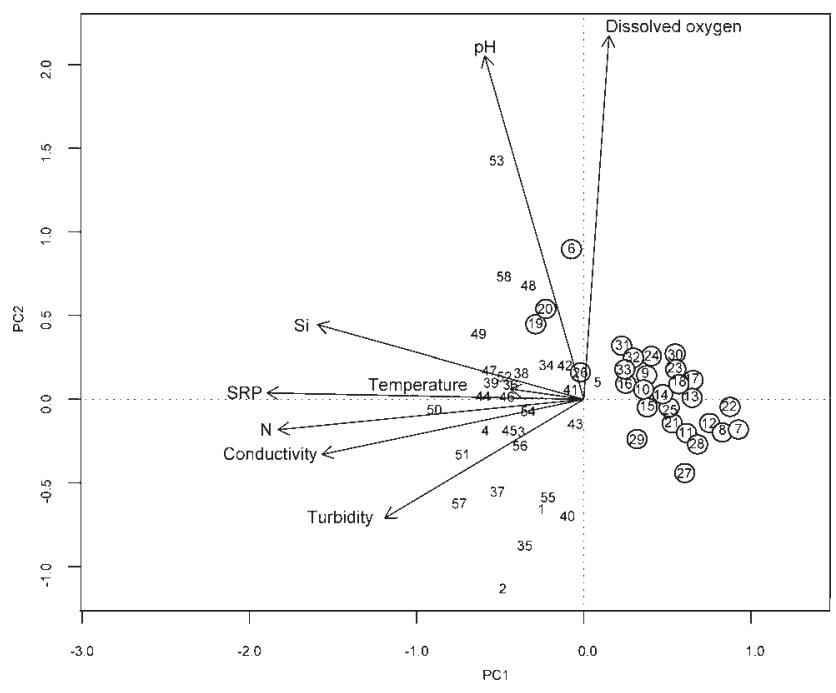

Fig. 2. Principal Components Analysis of the environmental variables in the Macquarie Island dataset. Circled sites are inland sites. $\mathrm{N}=$ nitrate/nitrite, $\mathrm{Si}=$ silicate, $\mathrm{SRP}=$ soluble reactive phosphate.

varied from $0-1571 \mu \mathrm{S} \mathrm{cm}^{-1}$ (mean $343 \mu \mathrm{S} \mathrm{cm}^{-1}$ ). The nutrient status of sites varied from oligotrophic to highly eutrophic (i.e. SRP ranged from $0-9890 \mu \mathrm{g} \mathrm{P} \mathrm{L}^{-1}$, mean $538.1 \mu \mathrm{g} \mathrm{P} \mathrm{L}^{-1}$; nitrate/nitrite from $0.15-8578 \mu \mathrm{g} \mathrm{N} \mathrm{L}^{-1}$, mean $831.1 \mu \mathrm{g} \mathrm{N} \mathrm{L}^{-1}$; and silicate from $2.15-2706 \mu \mathrm{g}$
$\mathrm{Si} \mathrm{L}^{-1}$, mean $\left.370.1 \mu \mathrm{g} \mathrm{Si} \mathrm{L}{ }^{-1}\right)$. Sites ranged from acidic to alkaline (i.e. pH 5.5-9.95, mean 7.15). Dissolved oxygen ranged from $4.73-18.08 \mathrm{mg} \mathrm{L}^{-1}$ (mean $11.43 \mathrm{mg} \mathrm{L}^{-1}$ ), temperature ranged from $4.49-13.48^{\circ} \mathrm{C}$ (mean $7.65^{\circ} \mathrm{C}$ ) and turbidity ranged from 6-2724 NTU (mean 121.6 NTU).

PCA of the environmental data indicated that nearly $50 \%$ of the variation in the environmental data was captured by the first two principal components (Table II). Variation along the first axis was explained by conductivity, nutrients and turbidity, with high nutrient and conductivity sites on the left hand side, and low nutrient and conductivity sites on the right hand side of the biplot. Variation along the second axis was explained by $\mathrm{pH}$ and dissolved oxygen (Fig. 2). The distribution of coastal and inland sites in Fig. 2 clearly illustrates the oceanic source and importance of conductivity and nutrients to the lakes.

\section{Exploring diatom-environment relationships}

In total, 208 diatom species were identified from 34 genera. Only those species occurring with a maximum relative abundance $\geq 1 \%$ were included in the statistical analyses (129 taxa). These taxa represent $96.5-100 \%$ (mean 99.1\%) of the total diatom count for each sample site. These taxa are listed in the Supplementary material (including their number

Table III. Abundant and common species in the dataset. Species in bold are both.

\begin{tabular}{|c|c|c|c|c|c|c|c|}
\hline Species & Code & $\mathrm{N}$ & Max & Mean & Mean (adj) & Med & Med (adj) \\
\hline \multicolumn{8}{|l|}{ Species occurring with $\geq 50 \%$ maximum relative abundance } \\
\hline Aulacoseira distans (Ehrenberg) Simonsen & CEN17 & 15 & 75.2 & 3.21 & 12.64 & $\mathbf{0}$ & 4.36 \\
\hline Cocconeis pediculus Ehrenberg & COC 8 & 12 & 50.0 & 2.32 & 11.43 & 0 & 2.73 \\
\hline Cyclotella meneghiniana Kützing & CEN15 & 5 & 52.9 & 0.96 & 8.07 & 0 & 0.44 \\
\hline Eunotia paludosa Grunow & UNK57b & 6 & 56.3 & 1.33 & 13.07 & 0 & 3.09 \\
\hline Fragilaria capucina Desmazieres & FRA8 & 33 & 97.9 & 25.07 & 44.82 & 1.8 & 39.46 \\
\hline Navicula sp. 1 & NAV63 & 13 & 52.7 & 1.75 & 7.93 & 0 & 3 \\
\hline $\begin{array}{l}\text { Planothidium delicatulum (Kutzing) } \\
\text { Round \& Bukthiyarova }\end{array}$ & ACH26 & 17 & 81.3 & 5.42 & 18.83 & $\mathbf{0}$ & 6.70 \\
\hline Planothidium quadripunctatum (Oppenheim) Sabbe & PLAhau & 24 & 70.4 & 6.12 & 15.06 & $\mathbf{0}$ & 3.28 \\
\hline $\begin{array}{l}\text { Psammothidium abundans (Manguin) } \\
\text { Bukhtiyarova \& Round }\end{array}$ & ACHsub2 & 24 & 95.1 & 8.9 & 21.88 & $\mathbf{0}$ & 12.7 \\
\hline Stauroneis sp. 1 & ACHsub & 31 & 62.5 & 3.72 & 7.08 & 0.17 & 2.94 \\
\hline Staurosira venter (Ehrenberg) Cleve \& Moller & CEN16 & 5 & 50 & 1.12 & 13.27 & 0 & 4.59 \\
\hline $\begin{array}{l}\text { Unknown sp. } 1 \\
\text { Species occurring at }>15 \text { sites }\end{array}$ & NAV32c & 15 & 74.3 & 3.51 & 13.8 & $\mathbf{0}$ & 1.71 \\
\hline Diatomella cf. balfouriana Greville & UNK37b & 15 & 11.74 & 0.71 & 2.78 & 0 & 1.67 \\
\hline Encyonema sp. 1 & AMP18a & 15 & 6.98 & 0.51 & 2.33 & 0 & 1.69 \\
\hline Gomphonema angustatum C.A. Agardh & GOMang & 15 & 6.1 & 0.45 & 2.05 & 0 & 1.47 \\
\hline Opephora marina (Gregory) Petit & OPE3 & 24 & 17.9 & 1.59 & 3.92 & 0 & 2.84 \\
\hline $\begin{array}{l}\text { Pinnularia subantarctica var. elongata (Manguin) } \\
\text { Van de Vijver \& Le Cohu }\end{array}$ & NAV55 & 15 & 2.94 & 0.26 & 1.16 & 0 & 0.86 \\
\hline $\begin{array}{l}\text { Planothidium lanceolatum (Brebisson) } \\
\text { Lange-Bertalot }\end{array}$ & PLAfre3 & 52 & 27.9 & 1.56 & 3.8 & 0 & 0.99 \\
\hline $\begin{array}{l}\text { Planothidium renei (Lange-Bertalot \& Schmidt) } \\
\text { Van de Vijver }\end{array}$ & $\mathrm{ACH} 25$ & 17 & 28.8 & 0.87 & 3.01 & 0 & 0.99 \\
\hline
\end{tabular}

Code $=$ species code used in ordination plots, $\mathrm{N}=$ number of occurrences, $\mathrm{Max}=$ maximum relative abundance, Mean $($ adj $)=$ non-zero mean, Med $=$ median, Med $(\operatorname{adj})=$ non-zero median. All species abundances are $\%$ relative abundance. 
Table IV. Detrended Correspondence Analysis results of species data (untransformed).

\begin{tabular}{lllll}
\hline Axes & \multicolumn{1}{c}{1} & \multicolumn{1}{c}{2} & \multicolumn{1}{c}{3} & \multicolumn{1}{c}{4} \\
\hline Eigenvalues & 0.790 & 0.528 & 0.379 & 0.387 \\
Length of gradient & 4.71 & 3.29 & 3.52 & 2.48 \\
\% Variance of species data explained & 9.73 & & & \\
Sum of all eigenvalues & 8.115 & & & \\
\hline
\end{tabular}

Table V. Canonical Correspondence Analysis results of all environmental and species data $(\log [\mathrm{x}+1]$ transformed $)$.

\begin{tabular}{llccc}
\hline Axes & 1 & 2 & 3 & 4 \\
\hline Eigenvalues & 0.556 & 0.250 & 0.156 & 0.117 \\
Cumulative \% variance of species & 9.95 & 14.49 & 17.54 & 19.77 \\
$\quad$ data & & & & \\
Sum of all canonical eigenvalues & 1.376 & & & \\
Sum of all eigenvalues & 5.112 & & & \\
\hline
\end{tabular}

of occurrences, mean, maximum and median relative abundances - see www.journals.cambridge.org/jin_ANS).

Twelve taxa were abundant in the calibration set, occurring with $\geq 50 \%$ relative abundance in at least one lake. Thirteen taxa were common, occurring in $\geq 15$ samples and six of these were both dominant and common: Stauroneis sp. 1, Planothidium quadripunctatum (Oppenheim) Sabbe, Staurosira venter (Ehrenberg) Cleve and Moller, Psammothidium abundans (Manguin) Bukhtiyarova and Round, Fragilaria capucina Desmazieres and Unknown sp. 1 (Table III).

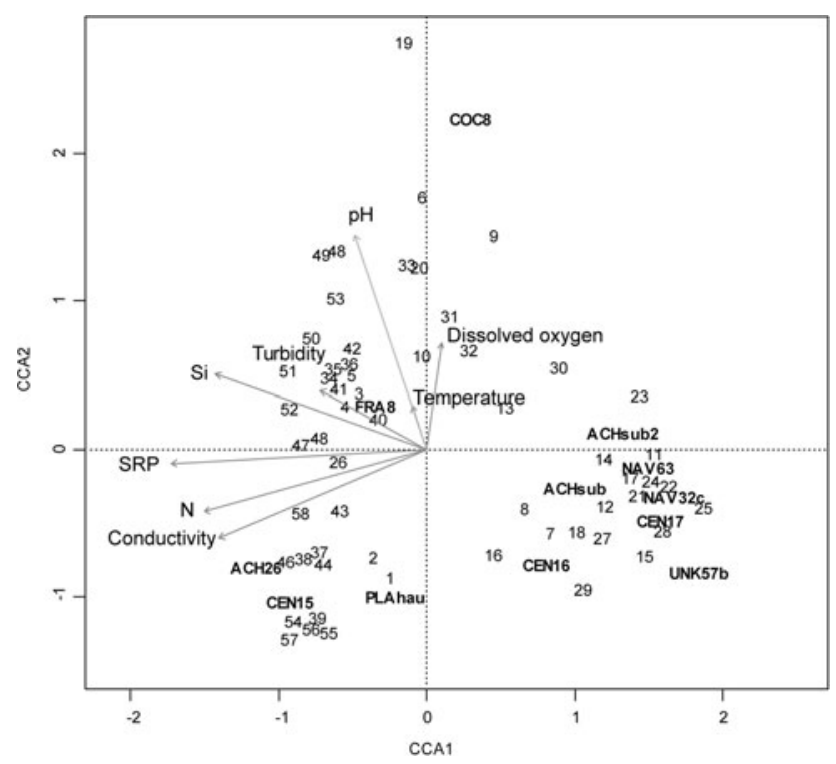

Fig. 3. Canonical Correspondence Analysis of the species and environment data. $\mathrm{N}=$ nitrate/nitrite, $\mathrm{Si}=$ silicate, $\mathrm{SRP}=$ soluble reactive phosphate.
Different diatom assemblages were present in inland lakes compared with coastal lakes. Inland lakes were dominated (i.e. species occurring $\geq 10 \%$ maximum abundance and in $\geq 10$ samples) by Aulacoseira distans (Ehrenberg) Simonsen, Cavinula pseudoscutiformis (Hustedt) Mann \& Stickle, Cocconeis pediculus Ehrenberg, Diatomella cf. balfouriana Greville, Fragilaria capucina, Navicula sp. 1, Planothidium quadripunctatum, Psammothidium abundans, Stauroneis sp. 1 and Unknown sp. 1. In contrast, the coastal lakes were dominated by Fragilaria capucina, Planothidium delicatulum (Kützing) Round and Bukhtiyarova, Planothidium lanceolatum (Brebisson) Lange-Bertalot and Planothidium quadripunctatum. Only Fragilaria capucina and Planothidium quadripunctatum were dominant in both coastal and inland lakes.

DCA of the species data (untransformed) clearly indicated that species distribution was unimodal (Table IV). An initial CCA indicated the environmental data explain $26.9 \%$ of the variation in the diatom data (Table V). As all VIFs were $<10$, all environmental variables were retained. The ordination plot indicated that SRP was highly correlated to axis 1 , while the remaining variables were correlated to both, but nitrate/nitrite and conductivity lay closer to axis 1 , while silicate was in between, and $\mathrm{pH}$ and dissolved oxygen were closer to axis 2 (Fig. 3).

CCAs of each environmental variable alone were performed (Table VI), followed by CCAs of individual environmental variables with the remainder as covariables to determine which made independent, significant contributions to explaining variation in the species data (i.e. $\mathrm{p}<0.05$, based on Monte Carlo permutation tests). This led to (in order) the removal of nitrate/nitrite, turbidity and dissolved oxygen, leaving conductivity, $\mathrm{pH}$, SRP,

Table VI. Individual Canonical Correspondence Analysis results. Note: $\mathrm{SRP}=$ soluble reactive phosphate.

\begin{tabular}{lccc}
\hline $\begin{array}{l}\text { Environmental } \\
\text { variable }\end{array}$ & $\begin{array}{c}\sum \\
\text { Canonical }\end{array}$ & $\begin{array}{c}\text { \% Variance } \\
\text { eigenvalues }\end{array}$ & $\begin{array}{c}\mathrm{p} \text { Value } \\
\text { explained }\end{array}$ \\
\hline Conductivity & 0.423 & 8.3 & $<0.005$ \\
Dissolved oxygen & 0.128 & 2.5 & 0.082 \\
Nitrate/nitrite & 0.441 & 8.6 & $<0.005$ \\
pH & 0.206 & 4.0 & $<0.005$ \\
SRP & 0.529 & 10.3 & $<0.005$ \\
Silicate & 0.380 & 7.4 & $<0.005$ \\
Temperature & 0.136 & 2.7 & 0.039 \\
Turbidity & 0.178 & 3.5 & 0.005 \\
\hline
\end{tabular}

Table VII. Canonical Correspondence Analysis results on the reduced model.

\begin{tabular}{lcccc}
\hline Axis & 1 & 2 & 3 & 4 \\
\hline Eigenvalues & 0.556 & 0.227 & 0.139 & 0.103 \\
Sum of canonical eigenvalues & 1.108 & & & \\
Sum of all eigenvalues & 5.112 & & & \\
\hline
\end{tabular}


Table VIII. Variance partitioning results. Note: SRP $=$ soluble reactive phosphate.

\begin{tabular}{|c|c|c|c|c|c|}
\hline Environmental variable & Covariable & $\sum$ Canonical eigenvalues & $\%$ Variance explained & $\%$ Interaction & $P$ Value \\
\hline \multirow{5}{*}{ Conductivity } & none & 0.423 & 8.3 & 0 & $<0.005$ \\
\hline & SRP & 0.147 & 2.9 & 5.4 & 0.01 \\
\hline & silicate & 0.271 & 5.3 & 3.0 & 0.005 \\
\hline & $\mathrm{pH}$ & 0.421 & 8.2 & 0.1 & $<0.005$ \\
\hline & Total interaction & & & 8.5 & \\
\hline \multirow[t]{4}{*}{ SRP } & none & 0.529 & 10.3 & 0 & $<0.005$ \\
\hline & temperature & 0.522 & 10.2 & 0.1 & $<0.005$ \\
\hline & $\mathrm{pH}$ & 0.519 & 10.2 & 0.1 & $<0.005$ \\
\hline & Total interaction & 10.2 & & & \\
\hline \multirow[t]{3}{*}{ Silicate } & none & 0.380 & 7.4 & 0 & $<0.005$ \\
\hline & conductivity & 0.227 & 4.4 & 3.0 & $<0.005$ \\
\hline & SRP & 0.143 & 2.8 & 4.6 & 0.005 \\
\hline & conductivity & 0.135 & 2.6 & 0.1 & 0.023 \\
\hline & SRP & 0.128 & 2.5 & 0.2 & 0.002 \\
\hline & silicate & 0.130 & 2.5 & 0.2 & 0.033 \\
\hline & $\mathrm{pH}$ & 0.140 & 2.7 & 0 & 0.005 \\
\hline & Total interaction & & & 0.5 & \\
\hline \multirow[t]{6}{*}{$\mathrm{pH}$} & none & 0.206 & 4.0 & 0 & $<0.005$ \\
\hline & conductivity & 0.205 & 4.0 & 0 & $<0.005$ \\
\hline & SRP & 0.196 & 3.8 & 0.2 & $<0.005$ \\
\hline & silicate & 0.171 & 3.3 & 0.7 & $<0.005$ \\
\hline & temperature & 0.210 & 4.1 & 0.1 & $<0.005$ \\
\hline & Total interaction & & & 1.0 & \\
\hline
\end{tabular}

silicate and temperature as the environmental variables that explained independent portions of the variance in diatom species distribution.

CCA of these variables indicated that they explain $21.7 \%$ of the variance in the species data and axes 1-4 explain $10.9 \%, 4.4 \%, 2.7 \%$ and $2.0 \%$ respectively (Table VII).

Variance partitioning indicated that there was a lot of interaction between conductivity, SRP and silicate, and that most of the interaction was due to silicate (Table VIII).

\section{Species optima and tolerances}

Simple WA was used to determine species optima and tolerances for conductivity, $\mathrm{pH}$, silicate, SRP and temperature. Species optima and tolerances are provided in the Supplementary material (www.journals.cambridge.org/ jin_ANS). There were clear transitions in the abundance and occurrence of the most abundant diatoms along the major environmental gradients (Fig. 4):

Aulacoseira distans, Eunotia paludosa, Navicula sp. 1 and Unknown sp. 1 were most abundant at low conductivity sites, while Planothidium delicatulum and Planothidium quadripunctatum were most abundant at higher conductivity sites.
Aulacoseira distans was the most abundant at acidic sites, while Cocconeis pediculus was most abundant at alkaline sites.

Eunotia paludosa, Stauroneis sp. 1 and Unknown sp. 1 were most abundant at low silicate sites, while Fragilaria capucina and Planothidium delicatulum were most abundant at high silicate concentrations.

Eunotia paludosa, Navicula sp. 1, Stauroneis sp. 1 and Unknown sp. 1 were most abundant at low SRP sites, while Cyclotella meneghiniana and Planothidium delicatulum were most abundant at high SRP sites.

Staurosira venter and Psammothidium abundans were most abundant at cooler sites, while Cocconeis pediculus and Unknown sp. 1 were most abundant at warmer sites (Fig. 4).

Table IX. Transfer function results. Note: SRP, silicate and temperature were $\log _{(\mathrm{x}+1)}$ transformed. SRP $=$ soluble reactive phosphate.

\begin{tabular}{lccccc}
\hline Variable & $r^{2}$ & $r_{\mathrm{p}}^{2}$ & RMSE & RMSE $_{\mathrm{p}}$ & Model \\
\hline Conductivity & 0.82 & 0.66 & 0.11 & 0.14 & WA $_{\text {cla }}$ \\
SRP & 0.90 & 0.80 & 0.40 & 0.50 & WA $_{\text {cla }}$ \\
Silicate & 0.91 & 0.61 & 0.25 & 0.53 & WAPLS-2 \\
pH & 0.70 & 0.29 & 0.44 & 0.68 & WA $_{\text {inv }}$ \\
Temperature & 0.56 & 0.23 & 0.06 & 0.08 & WA $_{\text {inv }}$ \\
\hline
\end{tabular}




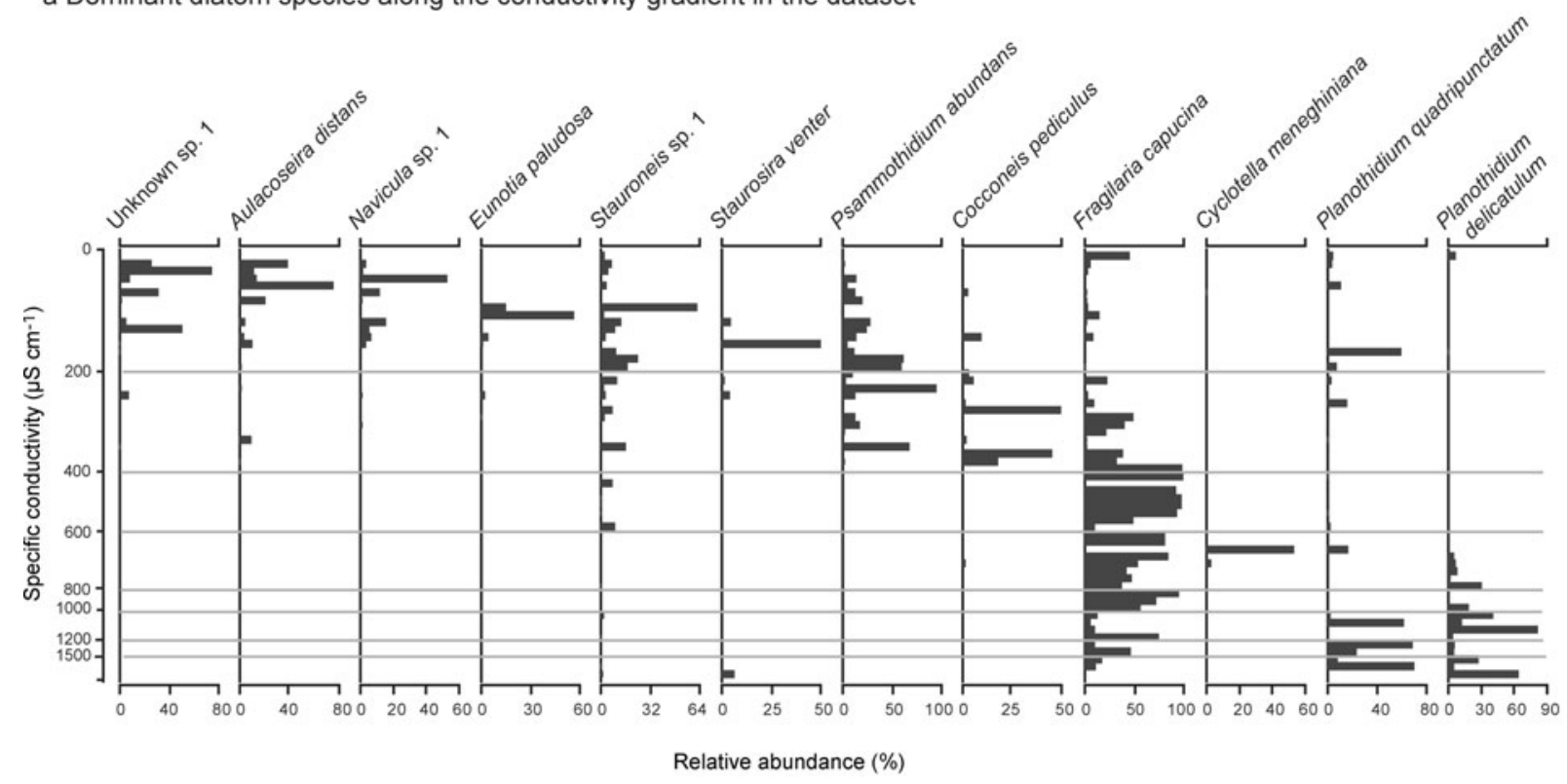

b Dominant diatom species along the $\mathrm{pH}$ gradient in the dataset

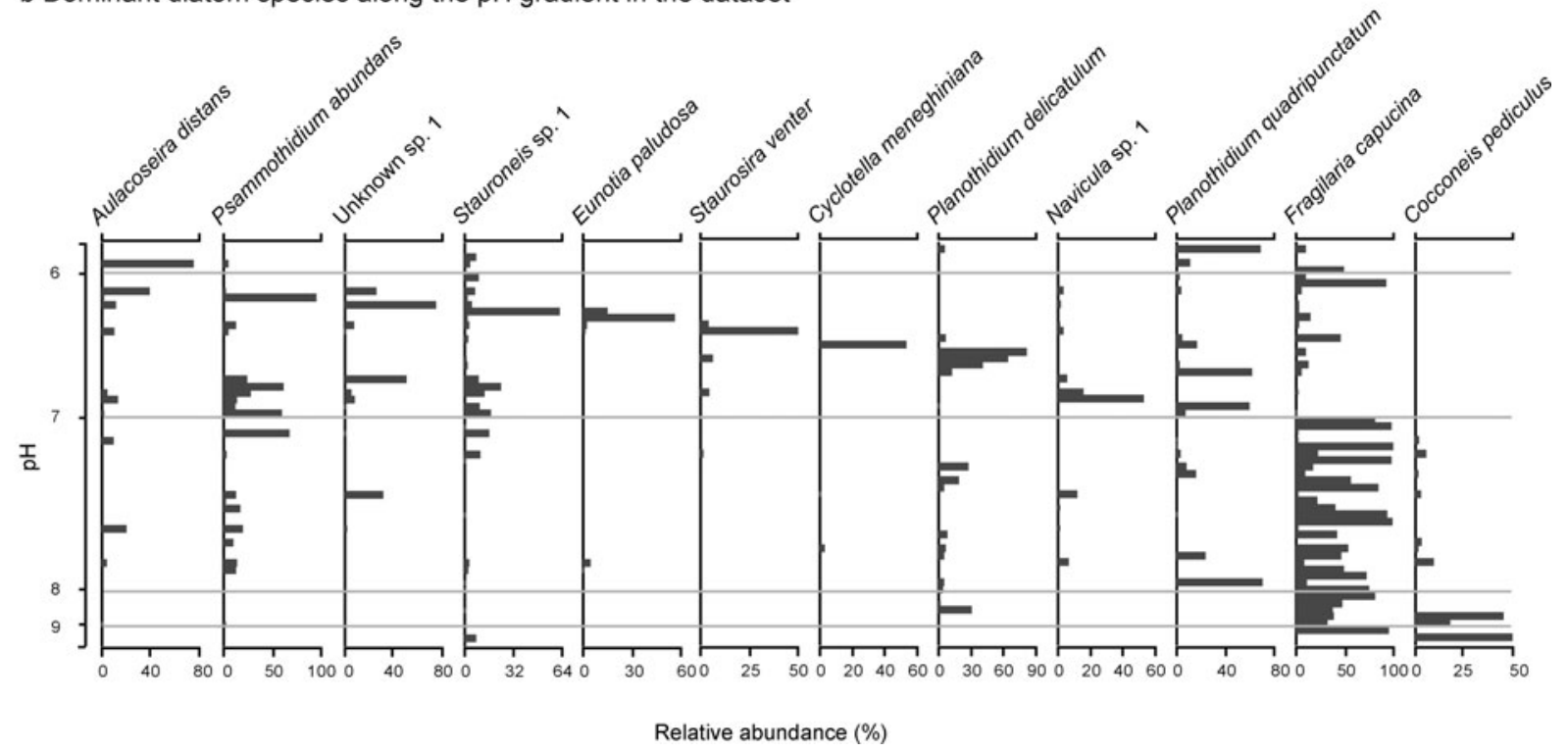

Fig. 4. Abundant diatom species distribution along the a. conductivity, b. $\mathrm{pH}$, c. silicate, d. soluble reactive phosphate and e. temperature gradients in the dataset, illustrating the strong environmental gradients in the dataset. Grey lines represent different zones within the environmental gradients. Species abundances are represented as \% relative abundance.

(Continued)

\section{Diatom-based transfer functions}

As $\mathrm{pH}$, SRP, conductivity, silicate and temperature explained independent portions of the variance in the diatom data, transfer functions for these were developed. Both simple WA and WAPLS were used to determine which model led to the best performing transfer function for each environmental variable (Table IX). Statistically robust transfer functions for SRP $\left(\mathrm{WA}_{\text {cla }} r^{2}=0.90, r^{2} \mathrm{p}=0.80\right.$,
RMSEp $\left.=0.50 \log \mu \mathrm{g} \mathrm{P} \mathrm{L} \mathrm{L}^{-1}\right)$, conductivity $\left(\mathrm{WA}_{\text {cla }}, r^{2}=\right.$ $\left.0.82, \quad r^{2} \mathrm{p}=0.66, \quad \mathrm{RMSEp}=0.14 \quad \mathrm{ppt}\right)$ and silicate (WAPLS-2, $\quad r^{2}=0.91, \quad r^{2} \mathrm{p}=0.61, \quad$ RMSEp $=0.53$ $\log \mu \mathrm{g} \mathrm{Si} \mathrm{L}^{-1}$ ) were developed. The $\mathrm{pH}$ and temperature transfer functions had relatively poor predictive performances $\left(\mathrm{WA}_{\text {inv }}, r^{2}=0.70, r^{2} \mathrm{p}=0.29\right.$, RMSEp $=$ 0.68 , and WAPLS- $2, r^{2}=0.56, r^{2} \mathrm{p}=0.23$, RMSEp $=$ $0.08 \log ^{\circ} \mathrm{C}$ respectively). 


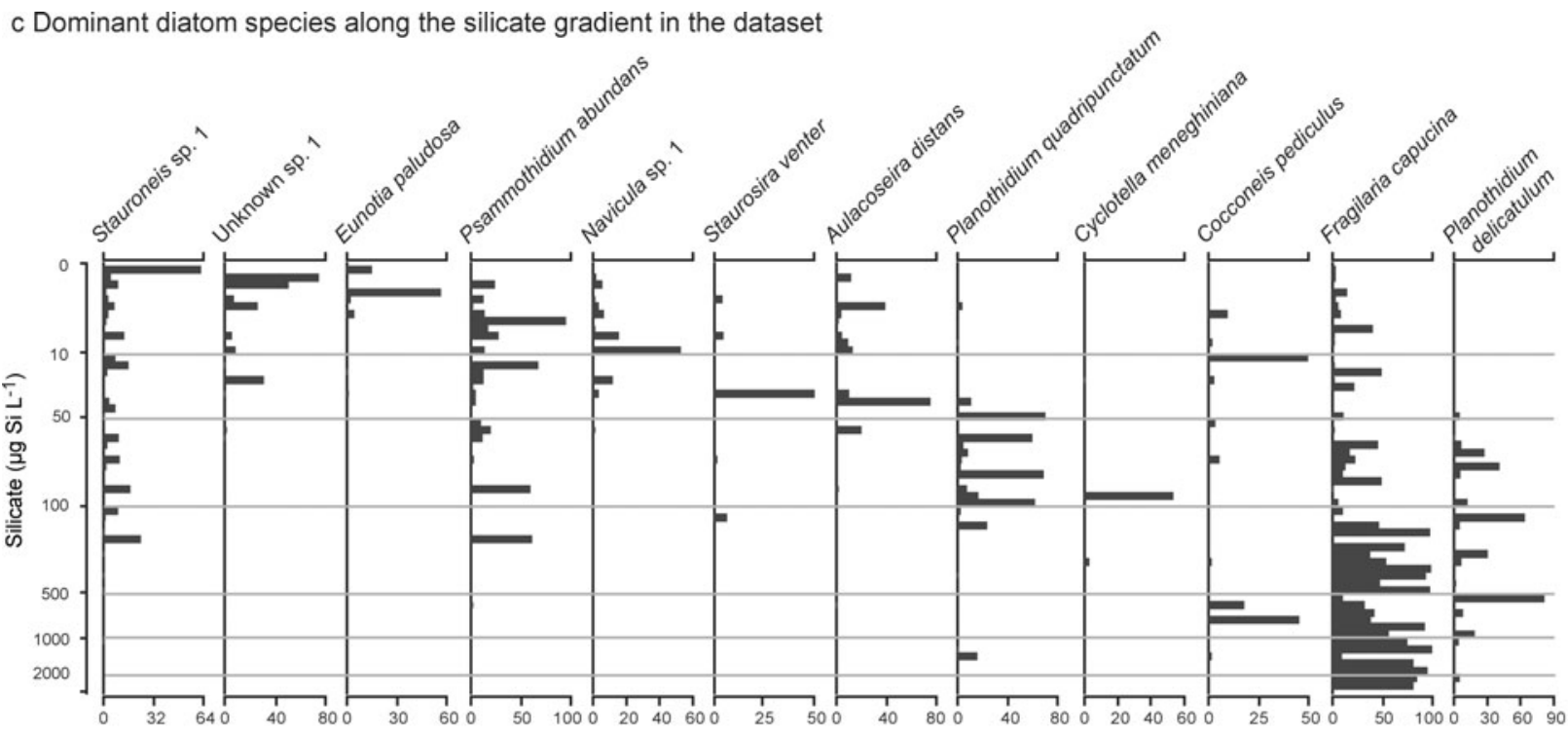

Relative abundance (\%)

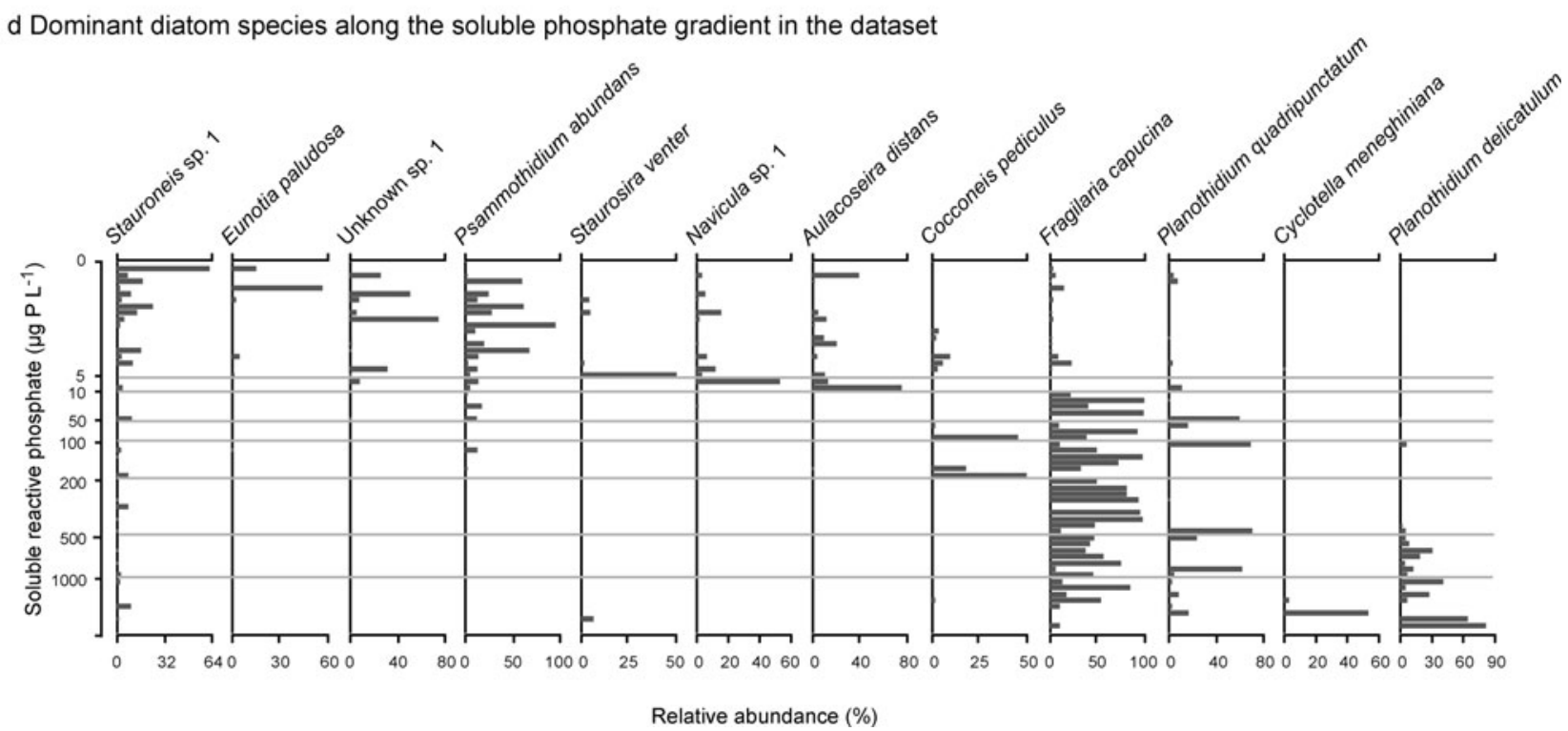

Fig. 4. Abundant diatom species distribution along the a. conductivity, b. $\mathrm{pH}$, c. silicate, d. soluble reactive phosphate and e. temperature gradients in the dataset, illustrating the strong environmental gradients in the dataset. Grey lines represent different zones within the environmental gradients. Species abundances are represented as \% relative abundance.

(Continued)

\section{Discussion}

The aims of this study were to investigate diatom assemblages in surface sediment samples from lakes on Macquarie Island, relate them to present-day environmental conditions and develop transfer functions for selected environmental variables. This has revealed new insights into the major limnological patterns on the island and the ecological preferences of diatoms on Macquarie Island across a range of environmental variables.

\section{Limnology}

The lakes analysed in this study are all freshwater. There is a wide range of nutrient concentrations ranging from mostly oligotrophic lakes on the plateau to eutrophic lakes on the coastal terrace. There are similar wide ranges in dissolved oxygen, $\mathrm{pH}$, temperature and turbidity. Eutrophic lakes and ponds commonly occur along the coastlines of subAntarctic and maritime Antarctic islands (e.g. Jones et al. 1993, Van de Vijver \& Beyens 1999). These lakes and 


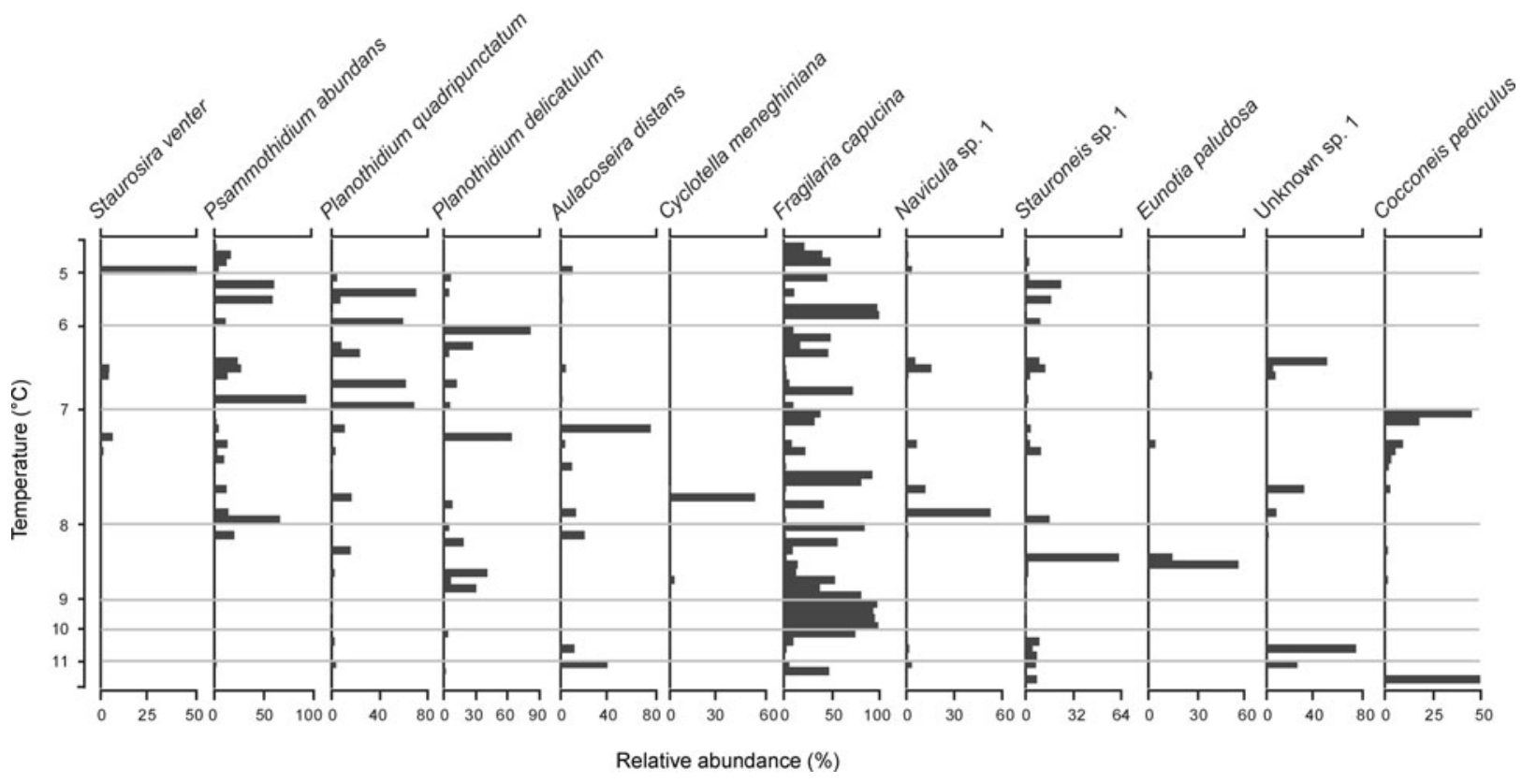

Fig. 4. Abundant diatom species distribution along the a. conductivity, b. $\mathrm{pH}$, c. silicate, d. soluble reactive phosphate and e. temperature gradients in the dataset, illustrating the strong environmental gradients in the dataset. Grey lines represent different zones within the environmental gradients. Species abundances are represented as \% relative abundance.

ponds can be highly eutrophic, reaching greater than $1000 \mu \mathrm{g}$ $\mathrm{P} \mathrm{L}^{-1}$ and $1000 \mu \mathrm{g} \mathrm{N} \mathrm{L}^{-1}$ (e.g. Ile de la Possession, Van de Vijver \& Beyens 1999, and this study, Table I). Seals, penguins and seabirds are considered to contribute significant amounts of nutrients and the highest SRP and nitrate/nitrite values recorded in this study were near seal or penguin colonies.

PCA of the environmental data shows that in addition to the influence of conductivity detected by Buckney \& Tyler (1974), the lakes are also organized along gradients of nutrients and turbidity, and to a lesser extent, $\mathrm{pH}$ and dissolved oxygen (Fig. 2). CCA with geographical and physical factors plotted as passive variables demonstrates the influence of distance from the west coast and the importance of the prevailing weather characteristics on conductivity, nutrients, $\mathrm{pH}$ and temperature (Fig. 5). With increasing distance from the west coast, these environmental variables decrease. All of the passive variables are highly correlated with each other, which is not surprising due to the westerly weather patterns that dominate the climate of Macquarie Island and the absence of lakes on the eastern coastal terrace.

\section{Ecological preferences of diatom communities on Macquarie Island}

The frequency distribution of selected taxa in the dataset provides examples of how individual species abundances respond to selected environmental variables (Fig. 6). This, together with clear transitions in species abundance and occurrence (Fig. 4), highlights the large limnological gradients in the lakes on Macquarie Island and allows potential indicator species to be identified.

Diatom taxa characteristic of higher nutrient and conductivity concentrations include Planothidium delicatulum and Cyclotella meneghiniana (Figs 4, 5 \& 7). These are both cosmopolitan species and Planothidium delicatulum has previously been found on the Antarctic continent, and Macquarie, Kerguelen, South Orkney and South Shetland islands (Van de Vijver et al. 2002b). Cyclotella meneghiniana has previously been found on Ile de la Possession by Van de Vijver \& Beyens (1999) when nutrient enrichment was sufficient and is common in eutrophic systems elsewhere (Weckström \& Juggins 2006). This appears to be the case in this study as well, as Cyclotella meneghinina was most abundant at a coastal site with high SRP and nitrate/nitrite (i.e. SRP $>2000 \mu \mathrm{g} \mathrm{P} \mathrm{L}{ }^{-1}$, nitrate/nitrite $>1900 \mu \mathrm{g} \mathrm{N} \mathrm{L}^{-1}$, Table I). Planktonic species are generally absent from Antarctic diatom assemblages (Jones et al. 1993), apart from some brackish to marine lakes in the Vestfold Hills, East Antarctica, where the diatom flora includes planktonic marine and sea ice diatoms (Verleyen et al. 2003). The general absence of planktonic diatom taxa in sub-Antarctic lakes is in contrast to lakes in temperate regions in the Southern Hemisphere, 


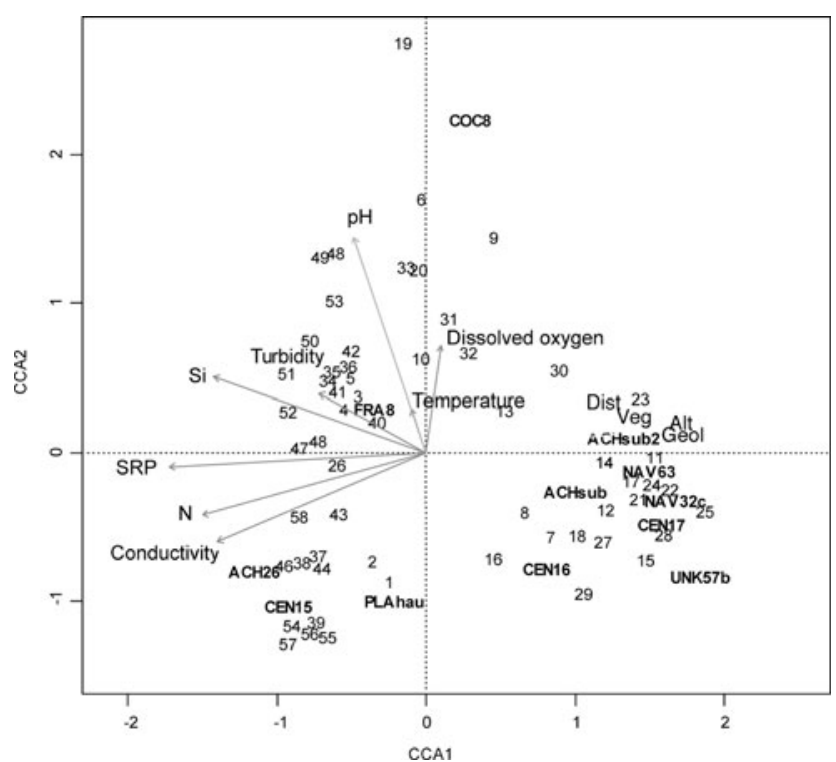

Fig. 5. Canonical Correspondence Analysis with passive geographical variables added, illustrating the influence of distance from the west coast and the importance of the prevailing weather characteristics on nutrients, $\mathrm{pH}$, conductivity and temperature in Macquarie Island lakes and ponds. Alt $=$ altitude, Dist $=$ distance from west coast, Geol $=$ geology, $\mathrm{N}=$ nitrate $/$ nitrite, $\mathrm{Si}=$ silicate, $\mathrm{SRP}=$ soluble reactive phosphate,

Veg $=$ surrounding vegetation cover type.

where planktonic diatoms often dominate (Van de Vijver \& Beyens 1999).

Aulacoseira distans, like Cyclotella meneghiniana, is a tychoplanktonic species that featured widely in this dataset, but only in inland lakes. It has also been identified on King George Island, South Georgia, lles Kerguelen and Crozet, and Ile de la Possession (Van de Vijver et al. 2002b). This is a heavily silicified species that needs water turbulence and/or high water levels to maintain suspension in the water column. A high or increasing abundance of Aulacoseira distans in diatom assemblages may indicate increased mixing intensity or lake level (Köster et al. 2004).

Psammothidium abundans is a benthic diatom associated with prostrate microbial mats (Verleyen et al. 2003). Diatom communities characteristic of low nutrient and conductivity conditions on Macquarie Island include Eunotia paludosa, which is characteristic of freshwaters elsewhere and is acidophilous, and Navicula sp. 1 and Unknown sp. 1, which have both been found elsewhere in the sub-Antarctic, but have yet to be fully identified and described (Bart Van de Vijver personal communication 2007).

\section{Evaluation of transfer functions}

Based on the dataset, statistically robust transfer functions for conductivity, SRP and silicate were developed (Table IX).
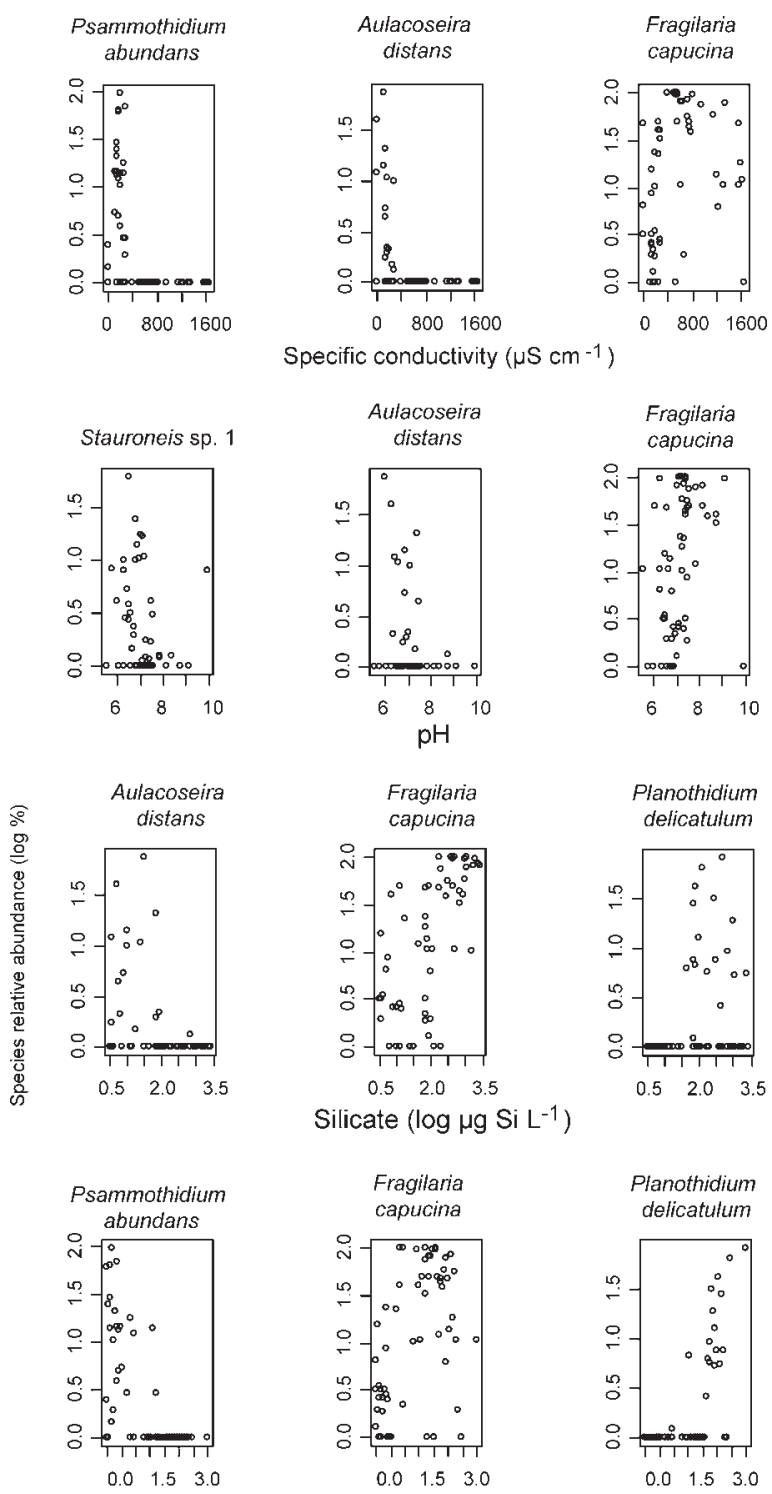

Soluble reactive phosphate $\left(\log \mu \mathrm{g} \mathrm{PL}^{-1}\right)$
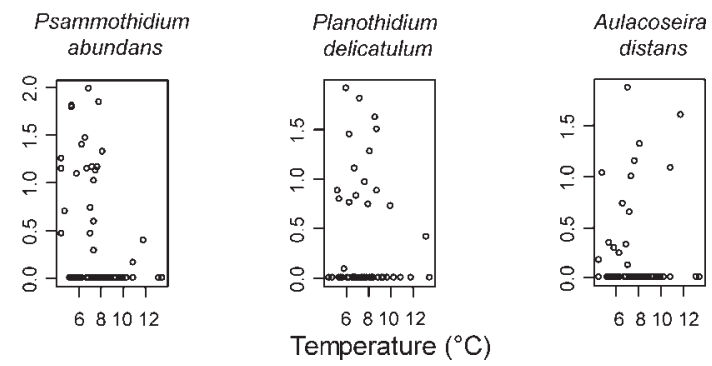

Fig. 6. Frequency distribution of selected abundant diatom taxa in the Macquarie Island reference dataset along the conductivity, $\mathrm{pH}$, silicate, soluble reactive phosphate and temperature gradients.

The best performing transfer function models used simple WA for conductivity and SRP, and WAPLS-2 components for silicate. The WAPLS model for silicate may have 
performed better than simple WA due to a reduction in the 'edge effect' (i.e. the underestimation of optima at the high end and overestimation at the low end of the gradient, Birks 1998) and the presence of more than one important environmental variable in the dataset (Verleyen et al. 2003). The distribution of species occurrence in the dataset illustrates the clear transitions in the dataset between species and changes in the concentration of each variable (Fig. 4).

The transfer functions for $\mathrm{pH}$ and temperature had relatively poor predictive performance (Table IX). This is surprising as there is a long, relatively well-populated $\mathrm{pH}$ gradient in the dataset. However, the diatoms seem to be pre-adapted to wide $\mathrm{pH}$ gradients and do not show the limited tolerances that are necessary to develop strong transfer functions. This is illustrated in the plot of diatom species occurrences along the $\mathrm{pH}$ gradient in the dataset: while some species only occur at low and high $\mathrm{pH}$, most occur throughout the $\mathrm{pH}$ gradient (Fig. 4). Similarly, the diatom-temperature transfer function performed poorly, probably due to the uneven distribution of lakes along the temperature gradient, with generally higher temperatures recorded in lakes located on the coastal terrace and lower temperatures recorded in lakes on the plateau. The influence of temperature is confounded by the influence of distance from the west coast and the importance of this in controlling the supply of nutrients and ions (conductivity) to the lakes. As indicated by a plot of the occurrence of dominant diatom species along the temperature gradient, the diatoms do not show quite as clear transitions as they do with other environmental variables, although some species appear to be more abundant at either end of the temperature gradient (Fig. 4). However, temperature can still be an important driving factor and diatom-temperature transfer functions have previously been developed for high latitude locations (e.g. Pienitz et al. 1995, Wolfe 2003, Gremmen et al. 2007).

Further sampling is planned to increase the number of samples in the dataset over a more evenly distributed altitudinal gradient to try and improve the performance of the diatom-temperature transfer function. Analyses of microfossil invertebrates are also underway to investigate the potential for developing an invertebrate-temperature transfer function.

\section{Potential applications of this dataset to climate change studies}

Understanding past rates and magnitudes of climate changes provides a fundamental basis for understanding recently observed rates of global warming and assessing the implications of this for the future.

The prevailing westerly winds are a dominant feature of Macquarie Island climate, and their latitudinal position shifts over time (Lamy et al. 2001). Toggweiler et al. (2006) demonstrated that warm climates, like the present, tend to have poleward-shifted westerlies, while cold climates like during the Last Glacial Maximum (LGM) have equatorward-shifted westerlies. Recent observations tend to support this as recent increases in global temperatures have coincided with poleward shifted westerlies (Shindell \& Schmidt 2004) and Marshall \& Connolly (2006) have shown that in the northern Antarctic Peninsula region, the current rising temperature trend is probably due to increased westerly wind strength, driven by increased greenhouse gas concentrations. Consequently, it is possible that poleward displacement of the southern westerlies could be involved in past periods of higher temperature and precipitation on both the sub-Antarctic islands and Antarctic Peninsula, while during periods where the westerlies move equatorward, these regions can be expected to adopt a more cold, dry Antarctic-like climate regime.

Recent examinations of global ocean temperature changes have shown warming in the upper $1000 \mathrm{~m}$ since the $1950 \mathrm{~s}$ (Gillie 2002). Warming in the Southern Ocean has been concentrated within the Antarctic Circumpolar Current (ACC) and has caused an average $8 \%$ increase in rainfall over the Southern Ocean and South Pacific since the late 1970s (Wong et al. 1999).

These changes are likely to occur at greater magnitude on longer glacial-interglacial timescales and involve movement of the fronts within the ACC, including the Polar Frontal Zone (PFZ). Marine core records from the Southern Ocean show that during the LGM the PFZ moved at least as far north as $52^{\circ} \mathrm{S}$, accompanied by a northward extension of sea ice extent and a major reduction in biological production (Crosta et al. 1998). As Macquarie Island is located at $54^{\circ} \mathrm{S}$, it is ideally placed to respond to changes in the position of the westerlies, provide information on migration of the PFZ poleward and equatorward, and respond to warming of the Southern Ocean. These factors control the climate of Macquarie Island by influencing wind, precipitation and temperature regimes, and this study shows that records of these changes are likely to be preserved in lake sediments on the island. The nutrient and conductivity transfer functions developed in this study may be applied to sub-fossil diatom assemblages in lake sediments on Macquarie Island to reconstruct nutrient and conductivity trends. Increased wind and rainfall can be expected to result in an increase in nutrients (from surface runoff) and conductivity (from sea spray) of the lakes (see the close association between nutrients, conductivity and turbidity, Figs 2 \& 4). These transfer functions can be applied over long time periods (i.e. glacial-interglacial timescales) to investigate nutrient and conductivity changes as a consequence of poleward and equatorward shifts in the westerlies and PFZ. Over shorter time periods, high resolution studies may allow sub-decadal patterns in wind and rainfall to be reconstructed. Applying quantitative reconstruction techniques to sediments from Macquarie Island lakes therefore has the potential to provide valuable insights into long-term ecological change, contributing to understanding changes in the Southern Ocean and climate change. 


\section{Potential applications of this dataset to human impact studies}

While Macquarie Island lakes respond to changes in climate, they are also vulnerable to direct human impacts. The greatest current threat is the rapidly expanding rabbit population. Rabbits were introduced in 1878 and with the recent removal of feral cats by 2001, the rabbit population has experienced a rapid increase in numbers. The major impact of this has been an increase in grazing pressure and burrowing, resulting in large areas of vegetation being destroyed, causing slope instability, erosion and loss of habitat (PWS 2007).

Diatom-inferred nutrient and conductivity trends will enable changes in lake water chemistry to be tracked and diatom analyses will record any changes in biodiversity as a result of these human impacts. With additional geochemical analyses, it should be possible to track changing feral animal populations. Similar work has been undertaken on Signy Island where seal hairs were used to track an expanding seal population following the decline and cessation of the whaling industry (Hodgson \& Johnston 1997) and on King George Island and Hope Bay where faecally derived elements have been used to track changes in penguin populations (Zale 1994, Sun et al. 2000). In the northern high latitudes, changes in nutrient inputs to lakes have been used to track the impact of changing seabird populations (Wagner \& Melles 2001). A similar approach could be used to reconstruct past animal populations on Macquarie Island.

\section{Conclusions}

Climate changes, in particular increasing wind, temperature and rainfall, and problems associated with feral animals, means that establishing baseline conditions before human arrival on Macquarie Island is a critical step in developing appropriate management strategies and targets to maintain the island's conservation and World Heritage status. This study has demonstrated that diatom-based palaeolimnological methods provide powerful tools to reconstruct past environments on Macquarie Island. Currently, the management and conservation strategies of Macquarie Island are focused on the present and future. What palaeolimnology can offer is an accurate reconstruction of past natural variability, a definition of baseline environmental conditions on the island prior to human contact and provides a way to track the nature and direction of subsequent environmental change. The success of future management efforts (such as the removal of non native species) can then be judged against these natural baselines.

\section{Acknowledgements}

This study was funded by an Australian Antarctic Science grant (2663). Krystyna Saunders is funded by an Australian
Postgraduate Award and an Australian Institute of Nuclear Science and Engineering Postgraduate Research Award. Dominic Hodgson is funded by the UK Natural Environmental Research Council CACHE-PEP Project at the British Antarctic Survey in collaboration with the HOLANT Project at the University of Ghent (Belgium). We would like to thank Donna Roberts for initially establishing the project, Bart van de Vijver for taxonomic assistance, Steve Juggins for advice on statistical analyses, Keith Springer for background knowledge on Macquarie Island, technical and logistical support, and Anthony Cowles for field assistance.

\section{References}

Battarbee, R.W., Jones, V.J., Flower, R.J., Cameron, N.G., Bennion, H., Carvalho, L. \& Juggins, S. 2001. Diatoms. In Smolm, J.P., Birks, H.J.B. \& LAsT, W.M., eds. Tracking environmental change using lake sediments: terrestrial, algal and siliceous indicators. Dordrecht: Kluwer, 155-202.

Birks, H.J.B. 1998. Numerical tools in palaeolimnology - progress, potentialities, and problems. Journal of Paleolimnology, 20, 307-322.

Brothers, N.P. \& Copson, G.R. 1988. Macquarie Island flora and fauna management - interpreting progress and predictions for the future. Papers and Proceedings of the Royal Society of Tasmania, 122, 129-136.

BRyden, M.M. 1988. Southern elephant seals as subjects for physiological research. Papers and Proceedings of the Royal Society of Tasmania, 122, 153-158.

Buckney, R.T. \& TyleR, P.A. 1974. Reconnaissance limnology of subAntarctic islands II: additional features of the chemistry of Macquarie Island lakes and tarns. Australian Journal of Marine and Freshwater, 25, 89-95.

Copson, G. \& Whinham, J. 2001. Review of ecological restoration programmes on subantarctic Macquarie Island: pest management progress and future directions. Ecological Management and Restoration, 2, 129-138.

Crosta, X., Pichon, J.J. \& Burckle, L.H. 1998. Reappraisal of Antarctic seasonal sea ice at Last Glacial Maximum. Geophysical Research Letters, 25, 2703-2706.

DAvis, B.W. 1988. Heritage conservation in Antarctic and subantarctic jurisdictions: the case of Macquarie Island. Papers and Proceedings of the Royal Society of Tasmania, 122, 9-14.

ERIKSEN, R. 1997. A practical manual for the determination of salinity, dissolved oxygen, and nutrients in seawater. Antarctic Cooperative Research Centre Report, No. 11. Hobart, TAS: Antarctic CRC, 83 pp.

GiLlie, S.T. 2002. Warming of the Southern Ocean since the 1950s. Science, 295, 1275-1277.

GLEW, J.R. 1991. Miniature gravity corer for recovering short gravity cores. Journal of Paleolimnology, 5, 285-287.

Gremmen, N.J.M., Van de Vijver, B., Frenot, Y. \& Lebouvier, M. 2007. Distribution of moss-inhabiting diatoms along the altitudinal gradient at sub-Antarctic Iles Kerguelen. Antarctic Science, 19, 17-24.

Hodgson, D.A. \& Johnston, N.M. 1997. Inferring seal populations from lake sediments. Nature, 387, 30-31.

Hodgson, D.A., Vyverman, W.G. \& Tyler, P.A. 1997. Diatoms of meromictic lakes adjacent to the Gordon River, and of the Gordon River estuary in south-west Tasmania. Bioliotheca Diatomologica, Band 35. Berlin: Cramer, 172 pp.

Hodgson, D.A., Roberts, D., McMinn, A., Verleyen, E., Terry, B., Corbett, C. \& Vyverman, W. 2006. Recent rapid salinity rise in three East Antarctic lakes. Journal of Paleolimnology, 36, 385-406.

Jones, V.J. \& BiRKs, H.J.B. 2004. Lake-sediment records of recent environmental change on Svalbard: results of diatom analysis. Journal of Paleolimnology, 31, 445-466. 
JoNES, V.J. \& JugGiNS, S. 1995. The construction of a diatom-based chlorophyll $a$ transfer function and its application at three lakes on Signy Island (maritime Antarctic) subject to differing degrees of nutrient enrichment. Freshwater Biology, 34, 433-445.

Jones, V.J., JugGins, S. \& Ellis-Evans, J.C. 1993. The relationship between water chemistry and surface sediment diatom assemblages in maritime Antarctic lakes. Antarctic Science, 5, 339-348.

JugGins, S. 2003. C2 User Guide. Software for ecological and palaeoecological data analysis and visualisation. Newcastle-uponTyne, UK: University of Newcastle.

Köster, D., Racca, J.M.J. \& Pienitz, R. 2004. Diatom-based inference models and reconstructions revisited: methods and transformations. Journal of Paleolimnology, 32, 233-246.

Kumke, T., Kienel, U., Weckstrom, J., Korhola, A. \& Hubberten, H.W. 2004. Inferred Holocene paleotemperatures from diatoms at Lake Lama, Central Siberia. Arctic Antarctic and Alpine Research, 36, 624-634.

Lamy, F., Hebbeln, D., Röhl, U. \& Wefer, G. 2001. Holocene rainfall variability in southern Chile: a marine record of latitudinal shifts in the southern westerlies. Earth and Planetary Science Letters, 185, 369-382.

Lim, D.S.S., Smol, J.P. \& Douglas, M.S.V. 2007. Diatom assemblages and their relationship to lakewater nitrogen levels and other limnological variables from 36 lakes and ponds on Banks Island, N.W.T., Canadian Arctic. Journal of Paleolimnology, 18, 313-333.

Marshall, G.J. \& Connolley, W.M. 2006. The effect of changing Southern Hemisphere winter sea surface temperatures on Southern Annular Mode strength. Geophysical Research Letters, 33, 10.1029/2006GL026627.

McGlone, M.S. 2002. The Late Quaternary peat, vegetation and climate history of the Southern Ocean islands of New Zealand. Quaternary Science Reviews, 21, 683-707.

Pienitz, R., Smol, J.P. \& Birks, H.J.B. 1995. Assessment of fresh-water diatoms as quantiative indicators of past climatic-change in the Yukon and Northwest-Territories, Canada. Journal of Paleolimnology, 13, 21-49.

PWS. 2007. Plan for the eradication of rabbits and rodents on Subantarctic Macquarie Island. Parks and Wildlife Service. Department of Tourism, Arts and the Environment, Tasmania, March 2007, 30 pp.

R Development Core Team. 2006. $R$ : a language and environment for statistical computing. R Foundation for Statistical Computing. Vienna, Austria (available from http://www.R-project.org).

Rintoul, S.R., Hughes, C.W. \& Olbers, D. 2001. The Antarctic Circumpolar Current system. In Siedler, G., Church, J. \& Gould, J., eds. Ocean, circulation and climate: observing and modeling the global ocean. London: Academic Press, 271-302.

Roberts, D. \& McMinn, A. 1999. Diatoms of the saline lakes of the Vestfold Hills, Antarctica. Bibliotheca Diatomologica, Band 44. Berlin: Cramer, $83 \mathrm{pp}$.

Sabbe, K., Hodgson, D.A., Verleyen, E., Taton, A., Wilmotte, A., Vanhoutte, K. \& Vyverman, W.G. 2004. Salinity, depth and the structure and composition of microbial mats in continental Antarctic lakes. Freshwater Biology, 49, 296-319.

SELKIRK, P.M., SEPPELT, R.D. \& SeLKIRK, D.R. 1990. Subantarctic Macquarie Island: environment and biology. Studies in Polar Research. Cambridge: Cambridge University Press, 285 pp.
Shindell, D.T. \& Schmidt, G.A. 2004. Southern Hemisphere climate response to ozone changes and greenhouse gas increases. Geophysical Research Letters, 31, 10.1029/2004GL020724.

Stoemer, E.F. \& Smol, J.P. 1999 The diatoms: applications for the environmental and earth sciences. Cambridge: Cambridge University Press, $469 \mathrm{pp}$.

Sun, L.G., XIE, Z.Q. \& ZHAO, J.L. 2000. Palaeoecology - a 3000-year record of penguin populations. Nature, 407, 858 .

Toggweiler, J.R., Russell, J.L. \& CArson, S.R. 2006. Midlatitude westerlies, atmospheric $\mathrm{CO}_{2}$, and climate change during the ice ages. Paleoceanography, 21, A2005-A2005.

Tweedie, C.E. \& Bergstrom, D.M. 2000. A climate change scenario for surface air temperature at Subantarctic Macquarie Island. In Davison, W., Howard-Williams, C. \& Broady, P., eds. Antarctic ecosystems: models for wider understanding Christchurch: Caxton Press, 272-281.

Van de ViJver, B. \& Beyens, L. 1999. Moss diatom communities from Ile de la Possession (Crozet, Subantarctica) and their relationship with moisture. Polar Biology, 22, 219-231.

Van de Vijver, B., Beyens, L., Vincke, S. \& Gremmen, N.J.M. 2004. Mossinhabiting diatom communities from Heard Island, sub-Antarctica. Polar Biology, 27, 532-543.

Van de Vijver, B., Ledeganck, P. \& Beyens, L. 2002a. Soil diatom communities from Ile de la Possession (Crozet, sub-Antarctica). Polar Biology, 25, 721-729.

VAn de Vijver, B., Frenot, Y. \& Beyens, L. 2002b. Freshwater diatoms from Ile de la Possession (Crozet Archipelago, Subantarctica). Bioliotheca Diatomologica, Band 46. Berlin: Cramer, 412 pp.

Verleyen, E., Hodgson, D.A., Vyverman, W.G., Roberts, D., McMinn, A., Vanhoutte, K. \& SabBe, K. 2003. Modelling diatom responses to climate induced fluctuations in the moisture balance in continental Antarctic lakes. Journal of Paleolimnology, 30, 195-215.

Vyverman, W., Vyverman, R., Hodgson, D.A. \& Tyler, P.A. 1995. Diatoms from Tasmanian mountain lakes: a reference dataset (TASDIAT) for environmental reconstructions and a systematic auteocological study. Bioliotheca Diatomologica, Band 33. Berlin: Cramer, 192 pp.

Wagner, B. \& Melles, M. 2001. A Holocene seabird record from Raffles Sø, East Greenland, in response to climatic and oceanic changes. Boreas, 30, 228-39.

WeCrström, K. \& Juggins, S. 2006. Coastal diatom-environment relationships from the Gulf of Finland, Baltic Sea. Journal of Phycology, 42, 21-35.

Wolfe, A.P. 2003. Diatom community responses to late-Holocene climatic variability, Baffin Island, Canada: a comparison of numerical approaches. Holocene, 13, 29-37.

Wong, A.P.S., BindofF, N.L. \& ChuRCh, J.L. 1999. Large scale freshening of intermediate waters in the Pacific and Indian Oceans. Nature, 400, $440-443$.

ZaLE, R. 1994. Changes in the size of the Hope Bay Adelie penguin rookery as inferred from Lake Boeckella sediments. Ecography, 17, $297-304$. 